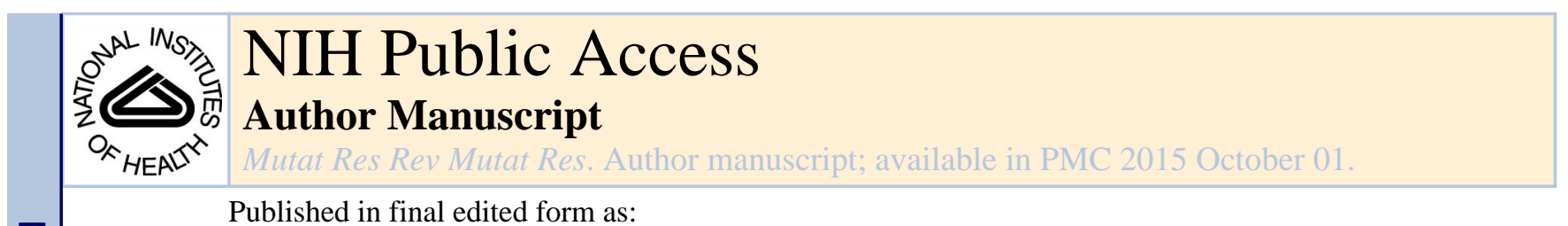

Published in final edited form as:

Mutat Res Rev Mutat Res. 2014 ; 762: 22-36. doi:10.1016/j.mrrev.2014.04.003.

\title{
Trichloroethylene Biotransformation and its Role in Mutagenicity, Carcinogenicity and Target Organ Toxicity
}

\author{
Lawrence H. Lash ${ }^{\mathrm{a}}$, Weihsueh A. Chiu ${ }^{\mathrm{b}}$, Kathryn Z. Guyton ${ }^{\mathrm{b}, \mathrm{d}}$, and Ivan Rusyn ${ }^{\mathrm{c}}$ \\ aDepartment of Pharmacology, Wayne State University School of Medicine, 540 East Canfield \\ Avenue, Detroit, MI, 48201 USA \\ bU.S. Environmental Protection Agency, 1200 Pennsylvania Avenue, NW, Washington, DC, \\ 20460 USA; Chiu.Weihsueh@.epa.gov; guytonk@iarc.fr
}

cEnvironmental Sciences and Engineering, University of North Carolina, Chapel Hill, NC 27599

USA; iir@unc.edu

\section{Abstract}

Metabolism is critical for the mutagenicity, carcinogenicity, and other adverse health effects of trichloroethylene (TCE). Despite the relatively small size and simple chemical structure of TCE, its metabolism is quite complex, yielding multiple intermediates and end-products. Experimental animal and human data indicate that TCE metabolism occurs through two major pathways: cytochrome P450 (CYP)-dependent oxidation and glutathione (GSH) conjugation catalyzed by GSH $S$-transferases (GSTs). Herein we review recent data characterizing TCE processing and flux through these pathways. We describe the catalytic enzymes, their regulation and tissue localization, as well as the evidence for transport and inter-organ processing of metabolites. We address the chemical reactivity of TCE metabolites, highlighting data on mutagenicity of these end-products. Identification in urine of key metabolites, particularly trichloroacetate (TCA), dichloroacetate (DCA), trichloroethanol and its glucuronide (TCOH and TCOG), and $N$-acetyl- $S$ (1,2-dichlorovinyl)-L-cysteine (NAcDCVC), in exposed humans and other species (mostly rats and mice) demonstrates function of the two metabolic pathways in vivo. The CYP pathway primarily yields chemically stable end-products. However, the GST pathway conjugate $S$-(1,2dichlorovinyl)glutathione (DCVG) is further processed to multiple highly reactive species that are known to be mutagenic, especially in kidney where in situ metabolism occurs. TCE metabolism is highly variable across sexes, species, tissues and individuals. Genetic polymorphisms in several of

(C) 2014 Elsevier B.V. All rights reserved.

Corresponding Author: Lawrence H. Lash, Ph.D., Department of Pharmacology, Wayne State University School of Medicine, 540 East Canfield Avenue, Detroit, MI 48201 USA, Tel: 1-313-577-0475; Fax: 1-313-577-6739; 1.h.lash@wayne.edu.

${ }^{\mathrm{d}}$ Current address: International Agency for Research on Cancer, Lyon, France

Conflict of Interest Statement

The authors declare that there are no conflicts of interest.

Publisher's Disclaimer: This is a PDF file of an unedited manuscript that has been accepted for publication. As a service to our customers we are providing this early version of the manuscript. The manuscript will undergo copyediting, typesetting, and review of the resulting proof before it is published in its final citable form. Please note that during the production process errors may be discovered which could affect the content, and all legal disclaimers that apply to the journal pertain.

Disclaimer:

The views expressed in this article are those of the authors and do not necessarily represent the views or policies of the U.S.

Environmental Protection Agency. 
the key enzymes metabolizing TCE and its intermediates contribute to variability in metabolic profiles and rates. In all, the evidence characterizing the complex metabolism of TCE can inform predictions of adverse responses including mutagenesis, carcinogenesis, and acute and chronic organ-specific toxicity.

\section{Keywords}

Cytochrome P450-dependent oxidation; glutathione conjugation; kidney; liver; reactive intermediates; trichloroethylene

\section{Introduction: Summary of trichloroethylene (TCE) metabolism}

TCE is a widespread environmental contaminant that has recently been classified as a human carcinogen by the International Agency for Research on Cancer (IARC) [1] and the U.S. Environmental Protection Agency (U.S. EPA) [2,3]. TCE metabolism plays a critical role in eliciting its mutagenicity, carcinogenicity and other adverse health effects. Indeed, with the exception of non-specific solvent effects on the neurological system, most organspecific toxicity has been attributed to specific TCE metabolites. TCE metabolism occurs through two major pathways in humans and laboratory animals, cytochrome P450 (CYP)dependent oxidation and glutathione (GSH) conjugation [2-5]. Quantitatively, flux through the CYP-dependent oxidation pathway far exceeds that through the GSH conjugation pathway in all species studied, including humans. Metabolites generated by the CYPdependent oxidation pathway are mostly chemically stable. However, the GSH conjugation pathway generates several highly reactive metabolites that are known to be mutagenic. Due to this difference in the chemical reactivity of the resulting metabolites, interpretations regarding toxicological importance based on quantitative differences in estimated flux of TCE metabolism through these two pathways must be made with caution.

TCE metabolism to mutagenic and toxic moieties remains a significant consideration for predicting and interpreting carcinogenic and other adverse responses to TCE. Additionally, key urinary metabolites from these pathways have utility for estimating exposure in environmental or occupational settings. For example, the American Conference of Governmental and Industrial Hygienists (ACGIH) recommends the use of urinary trichloroacetate (TCA) levels at the end of the work week as a metric for assessing occupational TCE exposure [6]; they recommend a limit of $100 \mathrm{mg}$ TCA/l.

While the basic outlines of the two TCE metabolism pathways depicted in Figs. 1 and 2 have been known for many years [7], additional characterization of metabolites in the past decade has greatly expanded the understanding of TCE metabolism. The sections that follow emphasize recently described metabolites and briefly summarize the major pathways of TCE metabolism, the resulting metabolites, and the enzymes involved. Information on the genotoxic potential of TCE metabolites is highlighted. Inter-organ distribution of TCE metabolites as depicted in Fig. 3 is also discussed. Important sources of variability in TCE metabolism, both within and across species, are identified. The chemical nature and reactivity of TCE metabolites are important determinants of target organ mutagenicity and 
tissue, sex, species, and individual differences in catalytic enzyme activity influence the resulting metabolic profiles and rates.

\section{CYP-dependent oxidation of TCE}

The overall scheme of TCE metabolism through CYP-dependent oxidation is shown in Fig. 1. Several of the resulting metabolites are chemically stable and have been detected in urine, as highlighted in Fig. 1. A summary of the major oxidative metabolites formed from TCE, their site of formation, the species (experimental animals, humans or both) in which they have been identified, and their systemic availability is included in Table 1 (top section). TCE metabolism by the oxidative pathway occurs predominantly in the liver [7]. Other tissues including the lungs [8-10], kidneys [11], and male reproductive organs [12,13] are also sites of CYP-mediated TCE metabolism. Chemical stability of the metabolite is an important determinant of systemic availability and fate. Relatively stable TCE metabolites may be transported from their site of formation into the bloodstream and delivered to other potential target organs. Chemically unstable and reactive end-products of TCE metabolism, on the other hand, can largely react with DNA, proteins, and lipids near their site of formation.

\subsection{TCE metabolites formed through the CYP-dependent oxidation pathway}

The initial step in TCE metabolism is catalyzed by one of several CYP enzymes and yields a chemically-unstable cytochrome P450-bound intermediate (TCE-O-CYP) [14]. A large number of metabolites are formed from TCE-O-CYP through either non-enzymatic rearrangement or specific enzymatic reactions. Specifically, TCE-O-CYP can have one of three fates: (1) conversion to chloral (CHL), which is in equilibrium with chloral hydrate (CH); (2) TCE-epoxide (TCE-O); or (3) $N$-hydroxy-acetyl-aminoethanol. Although Miller and Guengerich $[14,15]$ initially posited that unbound TCE-O did not form to an appreciable extent, subsequent studies by Cai and Guengerich [16-19] demonstrated that TCE-O is in fact generated. These results are consistent with the studies of Forkert [20] on 1,2-dichloroethylene metabolism in mouse Clara cells, which demonstrated formation of an epoxide by a CYP-dependent reaction.

The majority of the flux in CYP-dependent oxidation of TCE is towards CHL/CH [21] via chlorine migration in an oxygenated TCE-CYP transition state [14]. In fact, $\mathrm{CHL} / \mathrm{CH}$ is typically the most proximal stable metabolite recovered in incubations of tissues, cells, or microsomes with TCE [22]. CHL/CH undergoes either a reduction by alcohol dehydrogenase (ADH) [23] or CYP [24, 25] to generate trichloroethanol (TCOH). Oxidation of $\mathrm{CHL} / \mathrm{CH}$ by aldehyde dehydrogenase (ALDH) results in formation of trichloroacetic acid (TCA) [26, 27]. Rapid metabolism of CHL/CH in the liver, where the enzymes that participate in further metabolism are abundant, likely explains its detection in smaller amounts than in other tissues (e.g., lung) [10]. TCA is typically the major metabolite of TCE that is recovered, although TCOH is also a significant metabolite. TCOH can be oxidized by CYPs to yield TCA [25], or can undergo glucuronidation by UDP-glucuronosyltransferases (UGTs) to produce trichloroethanol glucuronide (TCOG) [28]. Enterohepatic recirculation of TCOG/TCOH is also known to occur [29]. Both TCOH and TCOG are recovered in 
urine. TCA may also undergo dechlorination to yield dichloroacetic acid (DCA) [30], albeit the relevance of these findings to in vivo metabolism has been questioned [31].

As illustrated in Fig. 1, there are several possible sources of DCA, including formation through the TCE-O intermediate. TCE-O spontaneously generates dichloroacetyl chloride (DCAC), a chemically unstable and reactive molecule, or oxalic acid (OA), a stable product that is excreted in urine. DCAC undergoes spontaneous dechlorination to produce DCA [32]. Past controversy and uncertainty about the accuracy of measurements of DCA formation highlight the complexity of the oxidative pathway. Conflicting results in the literature, some showing remarkably high levels of formation of DCA, led Ketcha and colleagues [33] to investigate and identify potential sources of artifacts. They concluded that the presence of strong acid in the assay solution causes dechlorination of TCA to DCA, thus overestimating the amount of DCA actually formed in vivo. In addition, kinetic analysis of blood levels of DCA and TCA following oral administration of TCE in the mouse also shows that TCA is not the only source of DCA in vivo $[34,35]$.

DCA has an extremely rapid disposition $[36,37]$ to glyoxylic, oxalic, and monochloroacetic acids. The major pathway for DCA biotransformation is complete dechlorination to glyoxylate in a reaction catalyzed by glutathione transferase $\zeta$ (GSTz) [38]. The glyoxylate is subsequently converted to oxalate, glycine, and $\mathrm{CO}_{2}$ [39]. DCA can also inactivate GSTz [40], which might lead to increased accumulation of DCA secondary to decreased elimination. Reductive monodehalogenation of DCA to monochloroacetic acid, albeit via an unknown in vivo mechanism, is a minor pathway that appears to increase with age in rats [41]. Interestingly, DCA is primarily metabolized by enzymes in the cytoplasm unlike other intermediates in the oxidative metabolism pathway (i.e., $\mathrm{CH}, \mathrm{TCOH}, \mathrm{TCA}$ ), which are metabolized by enzymes localized primarily in mitochondria and endoplasmic reticulum [42]. Elimination rates of DCA in rats and mice have been reported to be approximately one order of magnitude higher than those in humans [43]. Nonetheless, the U.S. EPA [2] concluded that these may still be high enough in humans to prevent significant accumulation of DCA under most typical exposure conditions.

A third major metabolite postulated to be formed from TCE-O-CYP or TCE-O intermediates is $N$-hydroxy-acetyl-aminoethanol [7]. Although few studies have investigated this metabolite, $N$-hydroxy-acetyl-aminoethanol was found in urine of rats and mice administered TCE and it was estimated that it is formed in amounts greater than those of DCA [44].

\subsection{Evidence for CYP-dependent oxidation of TCE in experimental animals}

Considerably more data on oxidative metabolism of TCE are available from experimental animal models than from humans or human tissue. Among experimental animal species, studies in rats and mice are the most numerous. These studies have informed identification of the enzymes involved, potential sources of variability, and factors modulating metabolism. In particular, rodent studies have demonstrated the participation of several CYP enzymes in TCE metabolism, including hepatic CYP2E1, CYP1A1/2, CYP2B1/2, and CYP2C11 [45-48]. Forkert et al. [9] also found mouse recombinant CYP2F2 to be active in TCE metabolism. Among several recombinant CYPs tested, rat CYP2E1 exhibited the 
highest catalytic efficiency for metabolism of TCE to $\mathrm{CH}\left(\mathrm{V}_{\mathrm{max}} / \mathrm{K}_{\mathrm{m}}=0.79\right)$ whereas that for recombinant mouse CYP2F2 was much lower $\left(\mathrm{V}_{\max } / \mathrm{K}_{\mathrm{m}}=0.11\right)$. Thus, although CYP2E1 is considered the primary CYP enzyme for TCE oxidation, other CYPs may play a role, particularly at higher TCE concentrations or in specific extrahepatic tissues. Studies by Kim and Ghanayem [49] with CYP2E1 knockout mice confirmed the predominance of this specific CYP enzyme in TCE metabolism, but also indicated that other CYPs can catalyze TCE oxidation. Although TCE was metabolized to CH in the CYP2E1 knockout mice, it is difficult from these data to extrapolate to normal animals and quantify the role of other CYPs when CYP2E1 is present.

Studies from several in vitro incubations with tissue homogenates clearly illustrate the presence of species-dependent differences in TCE oxidative metabolism. For example, the maximal rate of CYP-dependent oxidative metabolism of TCE is 2- to 4-fold faster in mice than in rats; in humans, the maximal rate of CYP-dependent oxidative metabolism of TCE is 5- to more than 10-fold slower than in rats [37, 50-52]. Maximal rates of TCE oxidative metabolism in rodents also differ between males and females. For example, Lash et al. [53] found higher concentrations of CYP-derived metabolites of TCE (i.e., $\mathrm{CH}, \mathrm{TCA}, \mathrm{TCOH}$ ) in livers of males than in females; the opposite pattern, however, was observed in kidneys. These results are consistent with higher maximal rates of CYP-dependent metabolism and overall metabolic clearance of TCE in male rats.

The potential role for variability in CYP activity, due to genetic polymorphisms or drugdrug interactions, in TCE metabolism has received some attention. Variability due to CYP polymorphisms has been suggested to have little impact on total flux of TCE metabolism for exposures below saturation, at which hepatic blood flow is limiting [2, 55]. As noted above, knockout of CYP2E1 in the mouse [49] does alter, but not completely abolish, liver CYPdependent TCE metabolism. However, CYP2E1 knockout had no effect on TCE toxicity in the lung [8]. Considerable inter-strain variability in formation of TCE metabolites from CYP-mediated oxidation of TCE has been also reported [56]. TCE $(2100 \mathrm{mg} / \mathrm{kg})$ was administered by intragastric lavage in corn oil to one hybrid and 14 inbred mouse strains; key metabolites were measured at 2,8 and $24 \mathrm{~h}$ in serum. At the 8-h time point (time of maximal metabolite levels in serum), TCA concentrations varied 4.5-fold (from approximately 400 to $1800 \mathrm{nmol} / \mathrm{ml}$ ) whereas DCA concentrations varied more than 100fold (from approximately 0.015 to $2 \mathrm{nmol} / \mathrm{ml}$ ).

Modulation of metabolic conditions with CYP inducers or inhibitors, or alterations in competing pathways, can significantly influence CYP-dependent metabolism of TCE [57]. For example, CYP2E1 induction by pyridine markedly increased TCE metabolism in both kidney and liver cells while attenuation of CYP activity with either a CYP2E1-specific (diethyldithiocarbamate) or a broad-spectrum CYP (metyrapone) inhibitor decreased CYPdependent TCE metabolism but enhanced GSH conjugation of TCE. While such modulations of CYP activity may not significantly impact the total metabolic flux, they can alter the balance between oxidation and GSH conjugation, as well as metabolism in extrahepatic tissues that are not flow-limited. Such impacts may also be even more substantial at higher substrate concentrations, where the $\mathrm{V}_{\max }$ may become more limiting than hepatic blood flow. 


\subsection{Evidence for CYP-dependent oxidation of TCE in humans}

The major oxidative metabolites of TCE, TCA, and TCOH or TCOG, have been detected in human studies in both blood and urine, providing empirical evidence of in vivo TCE oxidation in humans [58-63]. Limited information about CYP enzymes involved and their tissue distribution is available from human studies. CYP2E1 is the major CYP enzyme from human liver microsomes that metabolizes organic solvents, including TCE, vinyl chloride, ethylene dichloride, and others [46]. Besides CYP2E1, the other human CYP enzymes reported to have some activity with TCE as substrate include CYP1A1/1A2, CYP2A6, and CYP3A4. There is some disagreement regarding the role of CYP3A4 as Hissink et al. [64] did not detect measurable metabolism of TCE with purified human CYP3A4. Typical activity of CYP2E1 towards TCE is approximately 2-fold and 200-fold higher than that of CYP1A2 and CYP3A4, respectively [7].

CYP distribution may be one factor in determining species-specific differences in TCE metabolism. Although CYPs are distributed in many extrahepatic tissues, the distribution is not uniform across species in terms of either enzyme expression or activity. For example, while CYP2E1 is highly expressed in human liver and testes [12], it is expressed at very low levels in human kidney [65]. Although previous studies [11, 66, 67] detected neither CYP2E1 expression nor its activity in human kidney, use of a newly developed ELISA method showed human kidney cortex to contain about $15 \%$ of the level of CYP2E1 in human liver when normalized to microsomal protein (30-122 pmol CYP2E1/mg microsomal protein in liver vs. 5.0-22 pmol CYP2E1/mg microsomal protein). Moreover, when tissue weight and microsomal protein content are factored in, the total amount and activity of CYP2E1 in human liver is more than 50-fold higher than those in human kidney cortex. This sharply contrasts with the situation in rat kidney, which contains easily detectable levels of CYP2E1 and exhibits a relatively high rate of CYP2E1-dependent metabolism of TCE to $\mathrm{CH}$, TCA, and TCOH [68]. Hence, development of physiologically-based pharmacokinetic (PBPK) models for humans must take such significant species-dependent differences into account. Lipscomb et al. [69] modelled data on TCE oxidative metabolism in human liver microsomes and extrapolated rates in this in vitro system to account for total TCE metabolism in the human body. They concluded that the extrapolation modestly underestimated total metabolism and recommended inclusion of extrahepatic CYPdependent metabolism to increase the predictive value of the modelling approach. Similar conclusions were drawn from a Bayesian PBPK model-based analysis of toxicokinetic data on TCE metabolism in mice, rats and humans [70].

\subsection{Mutagenic potential of TCE metabolites formed through CYP-dependent oxidation}

The chemical reactivity and instability of TCE-O-CYP, TCE-O and DCAC suggest that adduction reactions with biological targets are likely. Indeed, irreversible binding of TCE metabolites from CYP-dependent oxidation to proteins and nucleic acids has been reported in a number of studies $[15,71,72]$. Additionally, studies of TCE genotoxicity in the liver, where oxidative metabolism would presumably predominate, are informative of the genotoxic potential of CYP-derived metabolites. For instance, Chang et al. [73] failed to detect any DNA single-strand breaks in the livers of rats at $4 \mathrm{~h}$ after single doses of 1-10 $\mathrm{mmol} / \mathrm{kg}$ of TCA, DCA, or monochloroacetate (MCA). However, they did detect small 
increases in the amounts of DNA single strand breaks (approximately 7\%) at $4 \mathrm{~h}$ in the livers of mice given the highest doses of TCA $(10 \mathrm{mmol} / \mathrm{kg}$ ) or DCA (5 or $10 \mathrm{mmol} / \mathrm{kg})$. In contrast, Leavitt et al. [74] reported a 1.3- or 2.3-fold increase in mutant frequency in transgenic $\mathrm{B} 6 \mathrm{C} 3 \mathrm{~F} 1$ mice harbouring the bacterial lacI gene after continuous exposure in the drinking water for 60 weeks to 1.0 or $3.5 \mathrm{~g} \mathrm{DCA} / 1$, respectively. H-ras codon 61 mutations distinct from those in spontaneous tumors were found in mouse liver tumors following DCA administration in the drinking water $(1.0$ or $3.5 \mathrm{~g} / \mathrm{l})$, whereas those following TCA administration in the drinking water $(4.5 \mathrm{~g} / \mathrm{l})$ exhibited the same mutational spectra as spontaneous tumors [75]. Mixed results are available for genotoxicity of TCE in mammalian cells in vitro [76]. One study in human lymphoblasts reported no DNA strand breaks after treatment with either MCA, DCA, TCA, or any of the corresponding aldehydes [73].

Numerous studies have also directly evaluated potential genotoxicity and mutagenicity of TCE metabolites formed through CYP-dependent oxidation, such as CH/CHL, DCA, TCA and, to a lesser extent, TCOH. Strong evidence is available to suggest that $\mathrm{CH} / \mathrm{CHL}$ may be genotoxic and mutagenic. The evidence is from both in vivo and in vitro tests, in mammalian and other experimental systems, including studies with and without metabolic activation [2, 76]. The types of damage reported include mutations, chromosomal aberrations, micronuclei, and cell transformation. Importantly, micronuclei in peripheral blood lymphocytes isolated from infants administered $\mathrm{CH}$ crystals mixed in breast milk or formula as a single dose of $50 \mathrm{mg} / \mathrm{kg}$ of body weight for sedation were significantly increased, consistent with the conclusion that $\mathrm{CH}$ is genotoxic in humans [77].

Evidence for other oxidative metabolites suggests a more limited mutagenic potential. The evidence that DCA may be genotoxic is weak to moderate. In bacterial and fungal test systems, only substitution mutation assays were positive [78]. TCA is generally regarded as not genotoxic. TCA was found to be overwhelmingly negative in bacteria and fungi [79, 80], in cultured human lymphocytes or lymphoblasts [73,81], or in mammalian in vitro studies $[82,83]$. Most animal in vivo studies found no evidence of genotoxicity of TCA [73, 81, 84, 85]. The mutational profile of mouse liver tumors following TCA administration is no different from those in spontaneous liver tumors in the same strain $[75,86]$. TCOH has not been evaluated in most recommended genotoxicity screening assays and thus the data should be interpreted with caution. One study found that $\mathrm{TCOH}$ was mutagenic in the presence of metabolic activation [87]; however, other studies were negative [80, 88].

\section{GSH conjugation of TCE}

TCE metabolism by the GSH conjugation pathway (Fig. 2) is initiated by the action of GSH $\mathrm{S}$-transferase (GST) enzymes. The first step in this pathway is an $\mathrm{S}_{\mathrm{N}} 2$ nucleophilic displacement reaction of TCE with GSH, releasing $\mathrm{Cl}^{-}$ion and $S-(1,2-$ dichlorovinyl)glutathione (DCVG) as products. Although this initial GSH conjugation step can occur in many tissues, it occurs primarily in the liver owing to first-pass metabolism and the high content of GSTs. In the human and rat liver, the various GST isoforms can account for as much as 5\% of total cytosolic protein [89]. Subsequent metabolism through the GSH conjugation pathway occurs primarily in the kidneys [7]. A summary of the site of formation and systemic availability of the major metabolites from the GSH-conjugation pathway is 
presented in Table 1 (bottom section). As noted above, although quantitatively the liver is the primary site of GSH conjugation of TCE in the body, the liver is very efficient at excreting GSH conjugates into either bile or plasma. Subsequently, through enterohepatic and renal-hepatic circulation, generally either the cysteine conjugate DCVC or the mercapturate NAcDCVC is delivered to the kidneys for further metabolism or excretion. Additionally, in situ GSH conjugation of TCE can occur within the kidneys themselves, primarily the proximal tubules [90-92], establishing an intra-organ cycle of GSH conjugate transport and metabolism (Fig. 3).

\subsection{TCE metabolites formed through the GSH conjugation pathway}

DCVG, whether formed within the kidneys or in the liver, is processed predominantly in the kidneys by a sequence of two hydrolytic enzymes on the proximal tubular brush-border membrane, $\gamma$-glutamyltransferase (GGT) and cysteinylglycine dipeptidase (DP), to yield the corresponding cysteine conjugate, $S$-(1,2-dichlorovinyl)-L-cysteine (DCVC) [93]. DCVC was first discovered more than 50 years ago in soybean meal as a by-product of TCE extraction [94]. It was identified as the agent causing nephrotoxicity and aplastic anemia in cows, but only nephrotoxicity in most other species. Lock and colleagues [95] verified that DCVC indeed produced both nephrotoxicity and aplastic anemia in cattle, but further showed that none of the other haloalkenyl cysteine conjugates studied caused aplastic anemia in addition to the characteristic nephrotoxicity.

DCVC can be viewed as a major branch point in this metabolic pathway, as it can have three possible fates [7, 96]. First, DCVC can be $N$-acetylated by the microsomal cysteine conjugate $N$-acetyltransferase (NAT) to form the mercapturate $N$-acetyl-S-(1,2dichlorovinyl)-L-cysteine (NAcDCVC) [97]. Besides excretion into urine, NAcDCVC can be deacetylated within the renal proximal tubular cell by aminoacylase III to re-form DCVC [98-100]. Additionally, mercapturates of several nephrotoxic haloalkenes, including NAcDCVC, are substrates for CYP3A enzymes to yield sulfoxides [101-103]. Thus, although NAcDCVC is considered a stable end-product of TCE metabolism and is recovered in urine, it can undergo additional metabolic transformations that serve to reactivate it. These additional fates of the putative end-product of the GSH conjugation pathway highlight both the complexity of TCE metabolism by this pathway and the potential difficulties in using urinary NAcDCVC as a surrogate measurement for overall flux through the GSH conjugation pathway.

Second, DCVC can be a substrate for cysteine conjugate $\beta$-lyase (CCBL) activities to generate the reactive $S$-(1,2-dichlorovinyl)thiol (DCVT). DCVT spontaneously rearranges to form either chlorothioketene (CTK) or chlorothionoacetyl chloride (CTAC) [104, 105]. Both of these species are chemically unstable and reactive and are believed to be responsible for formation of covalent adducts derived from DCVC with nucleic acids [106], proteins [107], and phospholipids [108]. CCBL activity has been detected not only in the kidneys, but in liver and other tissues as well. Only renal, as opposed to extra-renal, CCBL activity is toxicologically important for kidney toxicity because of the tissue localization of plasma membrane transporters and several of the enzymes of the GSH conjugation pathway that determine the distribution of TCE metabolites [109]. The overall $\beta$-lyase reaction 
mechanism is cleavage of a C-S bond to yield a reactive, thioacylating species. However, subsequent studies $[110,111]$ showed that the reaction mechanism can occur by either direct $\beta$-elimination or transamination with a suitable a-keto acid co-substrate to yield either the thiolate or a propionic acid derivative, respectively. The latter is chemically unstable and rearranges to release the thiolate. According to Cooper and colleagues [112,113], many distinct mammalian enzymes are known to be capable of catalyzing the CCBL reaction. Some of the CCBL enzymes catalyze both $\beta$-elimination and transamination reactions, whereas others can only catalyze the former reaction. The relative importance of each of these activities in DCVC bioactivation, however, is not presently known.

Third, DCVC can be a substrate for the flavin-containing monooxygenase (FMO), yielding a reactive $S$-(1,2-dichlorovinyl)-L-cysteine sulfoxide (DCVCS) [114]. The FMOs, like the CYPs, represent a multigene family of enzymes [115]. Both enzyme systems also share several other characteristics, including localization in the endoplasmic reticulum, requirement for NADPH as a reductant, and overall catalysis of a mixed-function oxidation reaction. Differences do exist, however, that make some of the functions of the FMOs rather distinctive. For example, although there are more than 50 individual functional CYP enzymes from > 40 gene families in humans [116], there are only 5 FMO genes in mammals. FMOs catalyze oxidation of sulfur-, selenium-, and nitrogen-containing chemicals [117]. Although FMOs and some CYPs share substrates and catalyze the same overall reactions, FMOs have some distinctive substrates, including cysteine $S$-conjugates of various haloalkenes and haloalkanes.

Because of the reactive nature of the various intermediates from this pathway, only NAcDCVC has been recovered in urine of both experimental animals $[62,118]$ and humans $[62,63]$ exposed to TCE or DCVC. Of the two possible bioactivation pathways for DCVC, the CCBL and FMO reactions, the former has received the most attention and is thought to account for most of the bioactivation activity for DCVC [7].

\subsection{Evidence for GSH conjugation of TCE in experimental animals}

Evidence for function of the GSH-dependent pathway in vivo in experimental animals comes from detection of either NAcDCVC in urine, or DCVG and DCVC in blood, serum or target tissues, primarily liver and kidney. Bernauer et al. [62], Commandeur and Vermeulen [119], and Larson and Bull [37] reported NAcDCVC in the urine of rats dosed with TCE. As with the case in humans exposed to TCE $[62,63,120]$, the ratio of oxidative metabolites of TCE (primarily TCA and TCOH/TCOG) to NAcDCVC was > 1000:1.

DCVG (up to $75 \mathrm{pmol} / \mathrm{g}$ liver) and DCVC (up to $400 \mathrm{pmol} / \mathrm{g}$ kidney) were detected in female, but not male, F344 rats administered TCE at up to $15 \mathrm{mmol} / \mathrm{kg}(1.97 \mathrm{~g} / \mathrm{kg})$ body weight by corn oil oral gavage [53]. The absence of detectable DCVG in liver or kidney of male rats is consistent with faster breakdown of DCVG in male rats than in female rats. DCVC, in contrast, was detected at levels of 5 to $9 \mathrm{pmol} / \mathrm{g}$ liver in female rats, 10 to 25 $\mathrm{pmol} / \mathrm{g}$ liver in male rats, 7 to $22 \mathrm{pmol} / \mathrm{g}$ kidney in female rats, and was not detectable in kidney tissue from male rats. DCVG was detected in whole blood of both male and female rats at levels ranging from 10 to $60 \mathrm{pmol} / \mathrm{ml}$ in males and 25 to $95 \mathrm{pmol} / \mathrm{ml}$ in females. DCVC was below the limit of detection in blood. 
Rusyn and colleagues $[34,35]$ detected both DCVG and DCVC in serum at levels as high as $\sim 40 \mathrm{pmol} / \mathrm{ml}$ and $2.4 \mathrm{pmol} / \mathrm{ml}$, respectively, in two studies of male B6C3F1 mice administered $2.1 \mathrm{~g}$ TCE/kg body weight by oral gavage. The amounts of serum DCVG in mice were very similar to those reported by Lash et al. [53] in rats. The ability of Kim et al. $[34,35]$ to detect DCVC at low levels, < $10 \%$ of those of DCVG, was achieved through the development of new, highly sensitive detection methods. The studies in rats and in mice provide clear in vivo evidence of function of the GSH-conjugation pathway for TCE metabolism. A follow-up study in a panel of 15 inbred mouse strains showed that DCVG levels in serum vary among strains and that DCVG is more abundant than DCVC [56]. Serum DCVG levels were below the limit of detection in 4 strains and varied between 2 and $40 \mathrm{pmol} / \mathrm{ml}$ in the other 11 strains. For DCVC, serum concentrations of this penultimate nephrotoxic and nephrocarcinogenic metabolite were below the limit of detection in 6 strains and varied between 1.5 and $3 \mathrm{pmol} / \mathrm{ml}$ in other strains.

While occurring in many tissues, the initial step in the GSH conjugation pathway, catalyzed by GST, is most rapid in liver. Lash et al. [92] compared rates of DCVG formation in incubations of 1 or $2 \mathrm{mM}$ TCE with $5 \mathrm{mM}$ GSH in suspensions of isolated hepatocytes and isolated renal proximal tubular cells from male F344 rats. Rates were about 20-fold higher in hepatocytes ( 5 to $10 \mathrm{nmol}$ DCVG formed $/ 10^{6}$ cells per 60 minutes) than in kidney cells $(0.3$ to $0.5 \mathrm{nmol}$ DCVG formed $/ 10^{6}$ cells per 60 minutes). Rates of GSH conjugation of TCE were also analyzed in liver and kidney microsomes and cytoplasm from male and female F344 rats and B6C3F1 mice to identify species-, sex-, and tissue-dependent differences. The rate of GSH conjugation of TCE was found to be markedly higher in mouse compared with rat tissues, modestly higher in male compared with female tissues and subcellular fractions, and markedly higher (5- to 25-fold) in liver than in kidney in the corresponding species and sex.

Several families of GST isoenzymes are expressed in mammalian tissues and little information is available concerning substrate specificity of each isoenzyme in general or with regard to TCE. Cummings et al. [121] investigated the GST isoform specificity towards TCE in renal cortical cytoplasm of male F344 rats. Using polyclonal antibodies specific to each isoform, they found that of the three classes of GSTs, only GSTa was detectable. Hence, only activity of the three GSTa dimers, GSTa1-1, GSTa1-2, and GSTa2-2, were assessed using GSTa isoform-selective inhibitors in isolated renal proximal tubular cells and purified GSTa1-2 isoforms. While all three specific GSTa enzymes exhibited similar $\mathrm{V}_{\max }$ towards TCE (75-150 pmol DCVG formed/min per mg protein), GSTa2-2 had a 50- to 100fold higher affinity $\left(\mathrm{K}_{\mathrm{m}}=0.074 \mathrm{mM}\right.$ TCE with $5 \mathrm{mM}$ GSH as co-substrate) than GSTa1-1 or GSTa1-2 ( $\mathrm{K}_{\mathrm{m}}=3.99$ and $7.51 \mathrm{mM}$, respectively). Studies with selective GST isoform inhibitors in renal proximal tubular cells, however, suggested that GSTa1-1 is the primary isoform that is functional in GSH conjugation of TCE in the intact rat kidney cell. These results contrast with those of Hissink et al. [64], who assessed the potential role of different GST isoforms in TCE metabolism by characterizing activity with several purified rat and human GSTs. They reported no activity for GSTa (GSTA) isoforms and significant activity with both GST $\mu$ (GSTM) and GST $\pi$ (GSTP) isoforms. Interestingly, these investigators measured DCVG formation at TCE concentrations ranging from $55 \mu \mathrm{M}$ to $1 \mathrm{mM}$ but 
observed no saturation and reported activity of rat GST $\mu 3-3$ with $0.25 \mathrm{mM}$ TCE as substrate of only $\sim 15 \mathrm{pmol} / \mathrm{min}$ per mg protein. Thus, it remains unclear which specific GST isoform is responsible for GSH conjugation of TCE.

DCVC metabolism by enzymes that possess CCBL activity can occur in either the cytoplasm or mitochondria. Studies of the CCBL-catalyzed reaction in vitro in kidney preparations, with DCVC as a substrate, show that in the rat this reaction is 3- to as much as 10-fold higher than that in analogous human kidney models [97, 110, 111, 122-128]. Rates of CCBL-dependent metabolism of DCVC in rats are considerably slower than those for the initial GSH conjugation step that yields DCVG, suggesting that the CCBL-mediated bioactivation reaction is rate-limiting for the conversion of TCE to nephrotoxic and/or mutagenic metabolites. Although DCVC-induced nephrotoxicity has been studied in mice, metabolic rates for $\mathrm{CCBL}$ for that species are not available in the literature.

The precise function of each of the various CCBLs in rat kidney in DCVC bioactivation is unclear. For example, although many studies have focused on CCBL/glutamine transaminase $\mathrm{K}$ (GTK) in renal cytoplasm as the enzyme responsible for CCBL-dependent metabolism of DCVC in that subcellular fraction [111, 125, 126, 128, 129], Cooper et al. [130] suggested that a high-molecular-weight enzyme ( $\mathrm{MW}=330 \mathrm{kDa})$ is actually responsible for most of the observed metabolic activity in the renal cytoplasm. There are also questions about the precise suborganellar localization of renal mitochondrial CCBL activity $[126,127]$ and the functional importance of several mitochondrial proteins possessing CCBL activity [126, 127, 131-135].

The other major enzyme system responsible for bioactivation of DCVC is the FMO system. Elfarra and colleagues [136-139] characterized the activity of what was initially detected as a cysteine conjugate S-oxidase and later determined to be a catalytic function of FMOs. Although several FMOs are expressed in rat kidney, FMO3 is the only isoform with significant activity for sulfoxidation of DCVC [136].

\subsection{Evidence for GSH conjugation of TCE in humans}

In a case report describing TCE ingestion in a 17 year old male attempting suicide, the mercapturate $N$-acetyl-S-(1,2-dichlorovinyl)-L-cysteine (NAcDCVC) was detected in urine, as were prominent CYP-derived metabolites, confirming function of the GSH-conjugation pathway for TCE metabolism in humans [90]. Quantitatively, the amount of recoverable NAcDCVC in urine of occupationally exposed workers is several orders of magnitude lower than that of TCA, the major urinary metabolite derived from the oxidative pathway [62, 63]. As noted above, because metabolites of the GSH-conjugation pathway are predominantly chemically reactive and unstable, measurement of NAcDCVC in urine indicates that flux through the pathway has occurred but does not provide an accurate quantitation of that flux. Goeptar et al. [122], Green et al. [97], and Bloemen et al. [140] used the higher ratio of TCA to NAcDCVC in urine and higher measured rates of CYP- versus GST-dependent metabolism in human liver samples to support conclusions that the GSH-conjugation pathway is a minor pathway in humans and that it is not toxicologically important. This conclusion has been challenged because of the consideration discussed above of the reactive 
nature of metabolites derived from the GSH-conjugation pathway, and given other data on human metabolism of TCE as discussed below.

Besides detection of the mercapturate in urine as an indicator of exposure to TCE, DCVG was detected in the blood of human volunteers exposed by inhalation to either $50 \mathrm{ppm}$ or $100 \mathrm{ppm}$ TCE for 4 hours [120]. Additionally, peak levels of and the area-under-the-curve (AUC) for DCVG were approximately 2-fold higher in males than in females, suggesting that males experience a higher exposure to reactive metabolite at a given dose of TCE and may be more susceptible to injury. Detection of this key intermediate in blood is consistent with what is known about the handling of GSH and GSH $S$-conjugates among tissues, a process referred to as "inter-organ metabolism" [141, 142] (Fig. 3).

There has been disagreement in the literature about the activity of GSH conjugation of TCE in human and rodent liver and kidney. Lash et al. [143] performed detailed kinetic analyses of GSH conjugation of TCE for human liver and kidney subcellular fractions in isolated hepatocytes and hepatic and renal cytoplasm and microsomes from humans. They reported rates and kinetics of DCVG formation that were generally in agreement with those reported for similar substrates by others. In contrast, Green et al. [97] reported rates of DCVG formation in human liver cytoplasm in vitro to be four orders of magnitude lower but did not perform detailed analyses of kinetics. Potential explanations for the differences relating to incubation conditions and analytical methods have been posited, but the controversy remains unresolved.

Four major GST isoforms are expressed in humans, GSTA, GSTM, GSTP, and GSTT [144-148]. Little information is available about the isoform specificity towards TCE, although Hissink et al. [64] reported similar values for purified human GSTM1-1 and GSTP1-1 and no activity with either purified human GSTA1-1, GSTA2-2, or GSTT1-1. Cummings et al. [66] reported that GSTA, GSTP, and GSTT, but not GSTM, proteins are all expressed in freshly isolated human proximal tubular cells. Interestingly, although only a limited number of human kidney samples were tested, both GSTA and GSTP protein expression exhibited a wide variation, consistent with the existence of genetic polymorphisms. In contrast, GSTT protein expression levels were nearly identical in all the samples. It is important, however, to determine if similar variations also exist in GST isoform expression in human liver as the liver is quantitatively the primary site of GSH conjugation of TCE.

Metabolism of DCVG to DCVC occurs in two steps, neither of which is rate-limiting for the overall flux through the GSH-conjugation pathway. Although humans have significantly lower GGT activity than rodents [149], GGT and DP activity on the brush-border plasma membrane of the proximal tubule of human kidney still far exceed that needed to metabolize even very high doses of DCVG. Thus, it is activity of the three enzymes that may subsequently act on DCVC, the CCBL, FMO, or NAT that determines overall flux.

Lash et al. [123] purified CCBL activity from human kidney cytoplasm and found that the intrinsic activity of the human cytoplasmic GTK protein was only about $10 \%$ of that from rat kidney cortex cytoplasm. Similarly, McGoldrick et al. [124] measured CCBL activity in 
primary cultures of proximal tubular cells from both rat and human kidney, and found activity in rat kidney cells to be threefold higher than that in human kidney cells. Studies in human kidney cytoplasm showed that CCBL activity towards DCVC occurred at a similar rate compared with other typical substrates [150] and that with a preparation of purified GTK from human kidney cytoplasm, was a modest substrate, exhibiting a nearly 3-fold higher rate than substrates like $\beta$-chloro-D,L-alanine and Se-methyl-L-selenocysteine but only about $35 \%$ of that of $S$-(1,1,2,2-tetrafluoroethyl)-L-cysteine [125]. Additionally, although transamination substrates like L-Phe, L-Gln, L-Met, or L-Leu exhibited 2- to 6-fold higher activity than transamination with DCVC, the rate of $\beta$-elimination with DCVC as substrate was much higher. Even though expression of CCBL/GTK was found in human kidneys [151], little information is available about the regulation or genetics of this enzyme or any of the other enzymes that may function as CCBLs. In a limited number of human kidney samples, however, McCarthy et al. [150] reported nearly fivefold inter-individual variation in rates of pyruvate formation, suggesting the possibility that genetic polymorphisms may also exist for the CCBL. Because of the function of CCBL activity in generating reactive, sulfur-containing metabolites from DCVC, this finding also suggests that such polymorphisms will be associated with differential mutagenic potentials.

Although metabolism by CCBL has received the most focus in studies of DCVC bioactivation, it may not be the most important pathway by which this occurs, at least in human kidney. Studies of DCVC metabolism and acute cytotoxicity in freshly isolated human proximal tubular cells [11] found little protection from toxicity by preincubation with the CCBL/GTK inhibitor aminooxyacetic acid (AOAA). This contrasts sharply with the situation in rat proximal tubular cells, where DCVC-induced cytotoxicity is almost completely prevented by pre-incubation with AOAA [126].

The alternate explanation for DCVC-induced cytotoxicity in human kidney cells is that FMO may play a more prominent role relative to CCBL whereas the reverse is likely true in rat kidney cells. While human kidney expresses FMO1, FMO3, and FMO5, the FMO1 isoform is the most highly expressed of the three and DCVC is only a substrate for FMO3 [152]. In fact, FMO1 expression averaged about 10-fold higher and FMO5 about 2.5- to 5fold higher than that of FMO3. Although the sulfoxide metabolite generated by the FMO reaction is extremely reactive [138], more study is needed to fully appreciate the role of this pathway in DCVC metabolism and toxicity in human kidney.

\subsection{Mutagenic potential of TCE metabolites formed through GSH conjugation}

TCE metabolism through GSH conjugation results in formation of several intermediates with mutagenic potential due to their instability and high reactivity. These include DCVT, CTK and CTAC (Fig. 2). Most of the experimental studies of genotoxicity and mutagenicity of GSH conjugation metabolites of TCE have been performed with DCVG, DCVC, DCVCS and NAcDCVC. Because traditional bacterial mutagenesis assays use liver-derived S9 fraction to test bioactivation, data obtained from such studies are less informative than experimental evidence obtained with kidney homogenates or purified enzymes responsible for biotransformation of TCE to GSH conjugation-derived reactive electrophiles. 
One published report examined the mutagenicity of DCVG in S. typhimurium strain TA2638 using kidney subcellular fractions for metabolic activation and the $\beta$-lyase inhibitor AOAA to inhibit genotoxicity [153]. DCVG exhibited direct-acting mutagenicity, with kidney mitochondria, cytoplasm, or microsomes enhancing the effects. The CCBL inhibitor diminished, but did not abolish the effects. Liver subcellular fractions did not enhance the mutagenicity of DCVG, consistent with kidney in situ metabolism playing a significant role in the genotoxicity of TCE metabolites through the GSH conjugation pathway.

DCVC has been the subject of numerous genotoxicity and mutagenicity studies. It was found to be mutagenic in S. typhimurium (strains TA100, TA2638, and TA98) using the Ames assay in the absence of S9 [154], and in S. typhimurium strain TA2638 with kidney subcellular fractions for metabolic activation [155]. A recent study confirmed these findings [156]. The genotoxicity of DCVC is further supported by the predominantly positive results in other available in vitro and in vivo assays. Unscheduled DNA synthesis was observed with DCVC treatment of Syrian Hamster fibroblasts [157] or LLC-PK1 cells [158]. Transformation of LLC-PK1 cells [159] or primary cultures of rat kidney cells [160] grown in the presence of DCVC was also reported. DCVC administered in vivo, in isolated perfused kidneys, and in isolated proximal tubules of albino male rabbits led to formation of DNA strand breaks [161]. In all the above studies, pretreatment with the CCBL inhibitor AOAA markedly diminished the mutagenic or genotoxic effect of DCVC, demonstrating the requirement for metabolism. In rats that were exposed orally to a single dose of DCVC (1 or $10 \mathrm{mg} / \mathrm{kg}$ ), no significant DNA damage in rat kidney proximal tubules was observed at the 16-hour sampling time with either dose, or after $1 \mathrm{mg} / \mathrm{kg} \mathrm{DCVC}$ at the 2-hour sampling time [162]. A statistically significant increase in percentage tail DNA 2 hours after treatment with $10 \mathrm{mg} / \mathrm{kg}$ DCVC was found, despite the small number of animals at each dose and sampling time.

Mutagenicity of NAcDCVC was investigated in S. typhimurium strain TA2638, using kidney subcellular fractions for metabolic activation and AOAA to inhibit genotoxicity [158]. NAcDCVC exhibited direct-acting mutagenicity in the absence of exogenous metabolic activation, with kidney cytoplasm enhancing the effects and AOAA diminishing, but not abolishing the effects.

DCVCS was found to be weakly mutagenic in S. typhimurium strain TA100 in the Ames salmonella mutagenicity assay [156]. DCVCS mutagenic activity was approximately 700fold lower than that of DCVC.

\section{Transport and inter-organ distribution of TCE metabolites}

Membrane transport and inter-organ translocation processes are important determinants of delivery of metabolic intermediates to sites of further metabolism or toxicity, and thus influence tissue distribution and handling of TCE metabolites [109, 141, 142]. These processes play a critical role in target organ specificity of TCE-induced adverse effects. Several oxidative metabolites, including $\mathrm{TCOH}$, exhibit complex time-dependent patterns consistent with enterohepatic circulation, with excretion of glucuronidated $\mathrm{TCOH}$ in bile, regeneration of free $\mathrm{TCOH}$ in the small intestine, and reabsorption of $\mathrm{TCOH}$ from the gut to 
the liver [7, 54]. Metabolites derived from GSH conjugation are also thought to undergo transport and transformation across multiple organs, including the liver, kidneys, and small intestine (Fig. 3).

Although GSH conjugation of TCE occurs predominantly in the liver, it can also occur in the kidneys. Hepatic DCVG is efficiently exported into either bile or plasma by efflux across the canalicular plasma membrane or sinusoidal plasma membrane, respectively. Biliary DCVG is largely degraded by GGT and DP activity to yield DCVC. Through enterohepatic circulation, this DCVC is returned to the liver where it undergoes $N$-acetylation to form the mercapturate NAcDCVC. Hepatic NAcDCVC is then exported to the kidneys for excretion in the urine. Both hepatic DCVG that is exported to plasma and intra-renal DCVG are efficiently translocated to the active site of renal GGT on the proximal tubular brush-border membrane, where it is degraded to DCVC.

A detailed summary of specific carrier proteins and the role of these transporters in GSH metabolism and turnover, susceptibility of the proximal tubules to oxidative and toxicant stresses, and modulation in disease and other pathological processes has been recently published [141]. DCVG that is presented to the kidneys can either undergo glomerular filtration and enter the tubular lumen or be in the renal periplasmic space. The former is metabolized by GGT and DP just as in the biliary tract to generate DCVC, which is transported into the proximal tubular cell by amino acid transporters for further metabolism. Renal plasma DCVG can be a substrate for one of three putative carriers on the basolateral plasma membrane. Work by Lash and Jones $[163,164]$ defined the processes of basolateral GSH uptake, demonstrating energy-dependent and both $\mathrm{Na}^{+}$-coupled and $\mathrm{Na}^{+}$-independent transport. They further showed that, like many membrane transporters, these carriers have somewhat broad substrate specificities and can also transport various $\gamma$-glutamyl amino acids and GSH $S$-conjugates, including DCVG [165]. Although substrate specificity and energetics studies proposed the potential function of three basolateral membrane carriers, the sodium dicarboxylate carrier-3 (NaC3; Slc13a3) and the organic anion transporter 1 and 3 (OAT1/3; Slc22a6/8), definitive evidence has only been obtained for the function of OAT3 [166].

\section{Variability in TCE metabolism and TCE metabolite transport}

Besides species differences, another important consideration for TCE metabolism in humans is inter-individual variability, with potential influences on both oxidative and GSH conjugation metabolism pathways. Lipscomb and colleagues [167] reported 2- to nearly 4fold variations in CYP content and a 5-fold range of rates of oxidative metabolism of TCE in human liver microsomes. This was most closely correlated with expression of CYP2E1 protein. Similarly, Elfarra et al. [50] reported a 4-fold variation in the rate of TCE metabolism to $\mathrm{CH}$ and $\mathrm{TCOH}$ in a limited number of samples of human liver microsomes. In addition to CYPs, particularly CYP2E1, overall metabolism of TCE by the oxidative pathway is also determined by expression and activity of ALDH and ADH (Fig. 1). Hence, variation in expression and/or activity of these enzymes may impact the rate at which TCE is cleared and converted to end-products such as TCOH, TCA, and DCA. The rate at which potentially mutagenic metabolites (i.e., $N$-hydroxy-acetyl-aminoethanol and DCAC) are 
formed will also vary according to these factors, presumably leading to variations in toxic outcomes. Major (up to 10-fold) inter-strain variation in both CYP- and GST-mediated metabolism of TCE has also been reported in mice [56]. It is important to note, however, that the limitations on variations in bioactivation imposed by hepatic blood flow may dampen the effects of differences in enzyme expression [55]. Lipscomb and colleagues [55] developed a PBPK model for study of TCE metabolism and demonstrated that hepatic blood flow delivers substrates to the liver at rates that are generally slower than those of the bioactivation reactions, thereby limiting the impact of differences in rates of those reactions.

In humans, three major underlying causes contribute to variation in expression and/or activity of drug metabolism enzymes, such as CYP2E1, ALDH, and ADH. The first cause is the existence of genetic polymorphisms, inherited mutations in genes that result in altered expression levels and/or activity of enzymes in at least $1 \%$ of the population. The overall implication of such genetic variation is that individuals with altered levels of a given enzyme may exhibit altered susceptibility to toxic effects of a chemical that is metabolized by that enzyme as compared to the rest of the population who express normal levels of the protein. Cataloguing of such individual variation and modulation of drug levels to account for this in a therapeutic regimen is the basis for the current drive for so-called "personalized medicine." For toxic chemicals such as TCE, application of these principles to human health risk assessment represents an important refinement whose potential is only recently being realized [168]. Bronley-Delancy et al. [26] investigated oxidative metabolism of TCE in cryopreserved human hepatocytes and found large inter-individual variation in kinetic parameters for TCOH and TCA formation. Cells were incubated with $\mathrm{CH}$ and $\mathrm{K}_{\mathrm{m}}$ values ranged between 0.001 to $2.44 \mathrm{mM}$ for $\mathrm{TCOH}$ formation and 0.005 to $1.27 \mathrm{mM}$ for TCA formation; similarly, $\mathrm{V}_{\max }$ values ranged between 0.54 and $222 \mathrm{nmol} \mathrm{TCOH}$ formed/min per $\mathrm{mg}$ protein and 0.14 to $158 \mathrm{nmol}$ TCA formed/min per mg protein. No correlation was seen, however, between $\mathrm{V}_{\text {max }}$ and ADH or ALDH genotype among the limited number of human liver samples. Polymorphisms in CYP2E1 are also known [169-171]. However, the potential impact of such polymorphisms on TCE metabolism was not investigated.

The second major underlying cause for human variation in drug metabolism enzyme expression and/or activity is the influence of prior or concurrent exposure to a chemical or drug that is a substrate for the enzyme in question. This exposure often results in either inhibition of activity or induction of enzyme expression. For example, ethanol is metabolized by CYP2E1, ADH, and catalase, and chronic exposure to ethanol leads to increased activity of CYP2E1 [172]. Such changes would be expected to increase metabolism of TCE.

The third major underlying cause of human variation in drug metabolism enzyme expression and/or activity is the existence of a disease or other chronic, pathological state. For example, chronic diseases such as diabetes modulate expression and activities of various drug metabolism enzymes and transporter proteins [173].

Genetic polymorphisms have also been identified for OAT1 and OAT3 [174-176]. Thus, different subpopulations of humans may have a markedly different capacity to accumulate DCVG or DCVC, thus altering their basic pharmacokinetics and susceptibility to 
nephrotoxicity. A better understanding of the implications of genetic polymorphisms in the genes for membrane transporters is relevant not only to toxicants but to therapeutics as well [177]. Further, expression and function of OATs and other organic anion transporters have been shown to exhibit gender-dependent differences in both humans and experimental animals [178-181], suggesting that transport differences are another contributing factor to gender differences in susceptibility to TCE metabolites. Protein kinase $\mathrm{C}$ or other signaling pathways can regulate gene expression or function of several of the organic anion transporters [182-184], adding another dimension to potential factors that can alter target cell accumulation of TCE metabolites.

\section{Summary and conclusions}

Despite nearly 40 years of research on the metabolism and target-organ toxicities associated with TCE, significant questions remain about how this environmental contaminant is handled in the body and its mechanisms of action in various target tissues. An appreciation of the chemical nature and reactivity of metabolites formed, how the enzymes involved are regulated, and tissue-, sex-, and species-specific differences are critical for understanding human health risks, including acute organ-specific toxicity, mutagenesis, and carcinogenesis. The complexities of TCE metabolism remain a continuing research challenge. Knowledge gaps persist regarding the extent of metabolism variability across target organs, species-, and individuals, including the amounts of reactive metabolites formed and their relative contribution to TCE-induced mutation and cancer.

There is consensus among experts that the CYP-mediated oxidation of TCE is a metabolic pathway that predominates quantitatively in all species studied, especially at environmentally-relevant concentrations or doses of TCE. Most of the TCE metabolites generated by the CYP-mediated oxidation pathway are chemically stable with evidence of systemic availability (Table 1) and urinary excretion (Fig. 1). With the exception of $\mathrm{CHL} / \mathrm{CH}$, these oxidative metabolites may contribute to carcinogenicity through mechanisms other than direct interaction with DNA. On the other hand, the high chemical reactivity and instability of metabolites generated by the GST pathway (Table 1 and Fig. 2) strongly argue for direct genotoxicity and mutagenicity as mechanistic events that may lead to cancer. A suggestion that the von-Hippel-Lindau tumor suppressor gene (VHL) mutations in renal cell carcinoma of subjects with occupational exposure to TCE are evidence of genotoxicity of TCE in humans $[185,186]$ has not been verified, and recent studies have reported $V H L$ mutations with high frequency in renal cell carcinoma, irrespective of exposure to TCE and other chlorinated solvents [187, 188]. Still, recent molecular epidemiology data demonstrating elevated kidney cancer risks among GST-active individuals, and attenuation among GST-null individuals [189], strongly supports the conclusion that GSH conjugation of TCE is toxicologically significant, at least for the kidney as a target organ. Furthermore, the influence of these genetic polymorphisms adds an additional degree of complexity and uncertainty to understanding TCE-induced mutagenicity and carcinogenicity.

The quantitative extent of TCE flux through the GSH conjugation pathway remains uncertain. Difficulties in quantifying flux through pathways that generate reactive species 
notwithstanding, new sensitive methods to quantify certain TCE metabolites are being developed and should help address remaining uncertainties in both human and experimental animal studies. Equally important is to determine the toxicity and mutagenicity of TCE metabolites from the GSH conjugation pathway in vivo. Few data are available from subchronic or chronic experimental animal studies to inform adverse health outcomes of DCVG and DCVC.

An additional, important consideration for human health risk assessment is variability in rates of TCE metabolism across species, tissues and individuals. For species differences, rates of both CYP- and GST-dependent flux are faster in rodents than in humans, with those in mice generally being markedly faster than in rats. Knowledge of such species differences in metabolic rates is important in using data from experimental animals to make predictions for humans, although differences in rates may not translate into differences in total flux, due to other physiological factors such as hepatic blood flow. For tissue differences, although the liver is universally the primary site of TCE metabolism amongst all species studied, extrahepatic sites are important for many tissue-specific effects in several species (Fig. 3). For individual variability, genetic polymorphisms exist for CYP2E1, GSTs, CCBL, and FMO, which need to be taken into account when making predictions for humans. Likewise, considerable variability in TCE metabolism has been observed among mouse inbred strains and understanding whether the inter-strain variability in TCE metabolism is associated with the differences in toxicity outcomes may provide important clues as to the quantitative underpinnings of various toxic effects of TCE, including mutagenicity [190]. Finally, the complexities of using epidemiology studies for understanding TCE metabolism and mechanisms of action are illustrated by a recent retrospective cohort study [191].

\section{Acknowledgments}

The authors wish to acknowledge the members of the IARC monograph 106 meeting panel and IARC staff for their criticism and suggestions in developing some of the text included in this review.

\section{Abbreviations}

ACGIH

ADH

ALDH

AOAA

AUC

BBM

BLM

CCBL

CH

CHL
American Conference of Governmental and Industrial Hygienists

alcohol dehydrogenase

aldehyde dehydrogenase

aminooxyacetic acid

area-under-the-curve

brush-border membrane

basolateral plasma membrane

cysteine conjugate $\beta$-lyase

chloral hydrate

chloral 


\begin{tabular}{|c|c|}
\hline $\mathbf{C M}$ & canalicular plasma membrane \\
\hline CTAC & chlorothionoacetyl chloride \\
\hline CTK & chlorothioketene \\
\hline CYP & cytochrome P-450 \\
\hline DCA & dichloroacetate \\
\hline DCAC & dichloroacetyl chloride \\
\hline DCVC & $S$-(1,2-dichlorovinyl)-L-cysteine \\
\hline DCVG & $S$-(1,2-dichlorovinyl)glutathione \\
\hline DCVS & $S$-(1,2-dichlorovinyl)-L-cysteine sulfoxide \\
\hline DCVT & $S$-(1,2-dichlorovinyl)-thiol \\
\hline DP & cysteinylglycine dipeptidase \\
\hline FMO & flavin-containing monooxygenase \\
\hline GGT & $\gamma$-glutamyltransferase \\
\hline GSH & glutathione \\
\hline GST & glutathione $S$-transferase \\
\hline GTK & glutamine transaminase $\mathrm{K}$ \\
\hline EPA & Environmental Protection Agency \\
\hline IARC & International Agency for Research on Cancer \\
\hline LC-MS/MS & liquid chromatography-tandem mass spectrometry \\
\hline MCA & monochloroacetate \\
\hline NAcDCVC & $N$-acetyl-S-(1,2-dichlorovinyl)-L-cysteine \\
\hline NAT & cysteine conjugate $N$-acetyltransferase \\
\hline $\mathbf{O A}$ & oxalic acid \\
\hline OAT & organic anion transporter \\
\hline PBPK & physiologically-based pharmacokinetic \\
\hline SM & sinusoidal plasma membrane \\
\hline TCA & trichloroacetate \\
\hline TCE & trichloroethylene \\
\hline TCE-O & trichloroethylene epoxide \\
\hline TCOG & trichloroethanol glucuronide \\
\hline ТСОН & trichloroethanol \\
\hline UGT & UDP-glucuronosyltransferase \\
\hline
\end{tabular}




\section{References}

[1]. Guha N, Loomis D, Grosse Y, Lauby-Secretan B, El Ghissassi F, Bouvard V, Benbrahim-Tallaa L, Baan R, Mattock H, Straif K, International Agency for Research on Cancer Monograph Working Group. Carcinogenicity of trichloroethylene, tetrachloroethylene, some other chlorinated solvents, and their metabolites. Lancet Oncol. 2012; 13:1192-1193. [PubMed: 23323277]

[2]. U.S. EPA. Toxicological Review of Trichloroethylene (CAS No. 79-01-6): In Support of Summary Information on the Integrated Risk Information System (IRIS). National Center for Environmental Assessment; Washington, DC: 2011.

[3]. Chiu WA, Jinot J, Scott CS, Makris SL, Cooper GS, Dzubow RC, Bale AS, Evans MV, Guyton KZ, Keshava N, Lipscomb JC, Barone S, Fox JF, Gwinn MR, Schaum J, Caldwell JC. Human health effects of trichloroethylene: key findings and scientific issues. Environ Health Perspect. 2013; 121:303-311. [PubMed: 23249866]

[4]. Chiu WA, Caldwell JC, Keshava N, Scott CS. Key scientific issues in the health risk assessment of trichloroethylene. Environ Health Perspect. 2006; 114:1445-1449. [PubMed: 16966103]

[5]. National Research Council. Assessing the Human Health Risks of Trichloroethylene: Key Scientific Issues. The National Academies Press; Washigton, DC: 2006.

[6]. American Conference of Governmental Industrial Hygienists, Biological Exposure Indices, BEI-25; Cincinnati. 1984;

[7]. Lash LH, Fisher JW, Lipscomb JC, Parker JC. Metabolism of trichloroethylene. Environ Health Perspect. 2000; 108(Suppl 2):177-200. [PubMed: 10807551]

[8]. Forkert PG, Millen B, Lash LH, Putt DA, Ghanayem BI. Pulmonary bronchiolar cytotoxicity and formation of dichloroacetyl lysine protein adducts in mice treated with trichloroethylene. $\mathrm{J}$ Pharmacol Exp Ther. 2006; 316:520-529. [PubMed: 16269531]

[9]. Forkert PG, Baldwin RM, Millen B, Lash LH, Putt DA, Shultz MA, Collins KS. Pulmonary bioactivation of trichloroethylene to chloral hydrate: relative contributions of CYP2E1, CYP2F, and CYP2B1. Drug Metab Dispos. 2005; 33:1429-1437. [PubMed: 15987776]

[10]. Odum J, Foster JR, Green T. A mechanism for the development of Clara cell lesions in the mouse lung after exposure to trichloroethylene. Chem Biol Interact. 1992; 83:135-153. [PubMed: 1505057]

[11]. Cummings BS, Lash LH. Metabolism and toxicity of trichloroethylene and S-(1,2-dichlorovinyl)L-cysteine in freshly isolated human proximal tubular cells. Toxicol Sci. 2000; 53:458-466. [PubMed: 10696794]

[12]. Forkert PG, Lash L, Tardif R, Tanphaichitr N, Vandevoort C, Moussa M. Identification of trichloroethylene and its metabolites in human seminal fluid of workers exposed to trichloroethylene. Drug Metab Dispos. 2003; 31:306-311. [PubMed: 12584157]

[13]. Forkert PG, Lash LH, Nadeau V, Tardif R, Simmonds A. Metabolism and toxicity of trichloroethylene in epididymis and testis. Toxicol Appl Pharmacol. 2002; 182:244-254. [PubMed: 12183104]

[14]. Miller RE, Guengerich FP. Oxidation of trichloroethylene by liver microsomal cytochrome P-450: evidence for chlorine migration in a transition state not involving trichloroethylene oxide. Biochemistry. 1982; 21:1090-1097. [PubMed: 7074051]

[15]. Miller RE, Guengerich FP. Metabolism of trichloroethylene in isolated hepatocytes, microsomes, and reconstituted enzyme systems containing cytochrome P-450. Cancer Res. 1983; 43:11451152. [PubMed: 6825087]

[16]. Cai H, Guengerich FP. Mechanism of Aqueous Decomposition of Trichloroethylene Oxide. J AM Chem Assoc. 1999; 121:11656-11663.

[17]. Cai H, Guengerich FP. Acylation of protein lysines by trichloroethylene oxide. Chem Res Toxicol. 2000; 13:327-335. [PubMed: 10813648]

[18]. Cai H, Guengerich FP. Reaction of trichloroethylene and trichloroethylene oxide with cytochrome P450 enzymes: inactivation and sites of modification. Chem Res Toxicol. 2001; 14:451-458. [PubMed: 11304134] 
[19]. Cai H, Guengerich FP. Reaction of trichloroethylene oxide with proteins and dna: instability of adducts and modulation of functions. Chem Res Toxicol. 2001; 14:54-61. [PubMed: 11170508]

[20]. Forkert PG. 1,1-Dichloroethylene-induced Clara cell damage is associated with in situ formation of the reactive epoxide. Immunohistochemical detection of its glutathione conjugate. Am J Respir Cell Mol Biol. 1999; 20:1310-1318. [PubMed: 10340951]

[21]. Byington KH, Leibman KC. Metabolism of trichloroethylene in liver microsomes. II. Identification of the reaction product as chloral hydrate. Mol Pharmacol. 1965; 1:247-254. [PubMed: 5842824]

[22]. Delinsky AD, Bruckner JV, Bartlett MG. A review of analytical methods for the determination of trichloroethylene and its major metabolites chloral hydrate, trichloroacetic acid and dichloroacetic acid. Biomed Chromatogr. 2005; 19:617-639. [PubMed: 15828053]

[23]. Sato A, Nakajima T, Koyama Y. Dose-related effects of a single dose of ethanol on the metabolism in rat liver of some aromatic and chlorinated hydrocarbons. Toxicol Appl Pharmacol. 1981; 60:8-15. [PubMed: 7281179]

[24]. Shultz J, Weiner H. Alteration of the enzymology of chloral hydrate reduction in the presence of ethanol. Biochem Pharmacol. 1979; 28:3379-3384. [PubMed: 43731]

[25]. Ni YC, Wong TY, Lloyd RV, Heinze TM, Shelton S, Casciano D, Kadlubar FF, Fu PP. Mouse liver microsomal metabolism of chloral hydrate, trichloroacetic acid, and trichloroethanol leading to induction of lipid peroxidation via a free radical mechanism. Drug Metab Dispos. 1996; 24:81-90. [PubMed: 8825194]

[26]. Bronley-DeLancey A, McMillan DC, McMillan JM, Jollow DJ, Mohr LC, Hoel DG. Application of cryopreserved human hepatocytes in trichloroethylene risk assessment: relative disposition of chloral hydrate to trichloroacetate and trichloroethanol. Environ Health Perspect. 2006; 114:1237-1242. [PubMed: 16882532]

[27]. Lipscomb JC, Mahle DA, Brashear WT, Garrett CM. A species comparison of chloral hydrate metabolism in blood and liver. Biochem Biophys Res Commun. 1996; 227:340-350. [PubMed: 8878519]

[28]. Muller G, Spassowski M, Henschler D. Metabolism of trichloroethylene in man. III. Interaction of trichloroethylene and ethanol. Arch Toxicol. 1975; 33:173-189. [PubMed: 1173750]

[29]. Merdink JL, Stenner RD, Stevens DK, Parker JC, Bull RJ. Effect of enterohepatic circulation on the pharmacokinetics of chloral hydrate and its metabolites in F344 rats. J Toxicol Environ Health A. 1999; 57:357-368. [PubMed: 10405189]

[30]. Moghaddam AP, Abbas R, Fisher JW, Stavrou S, Lipscomb JC. Formation of dichloroacetic acid by rat and mouse gut microflora, an in vitro study. Biochem Biophys.Res Commun. 1996; 228:639-645. [PubMed: 8920962]

[31]. Moghaddam AP, Abbas R, Fisher JW, Lipscomb JC. The role of mouse intestinal microflora in the metabolism of trichloroethylene, an in vivo study. Human Exp Toxicology. 1997; 16:629635.

[32]. Davidson IWF, Beliles RP. Consideration of the target organ toxicity of trichloroethylene in terms of metabolite toxicity and pharmacokinetics. Drug Metabolism Reviews. 1991; 23:493599. [PubMed: 1802654]

[33]. Ketcha MM, Stevens DK, Warren DA, Bishop CT, Brashear WT. Conversion of trichloroacetic acid to dichloroacetic acid in biological samples. J Anal Toxicol. 1996; 20:236-241. [PubMed: 8835661]

[34]. Kim S, Kim D, Pollack GM, Collins LB, Rusyn I. Pharmacokinetic analysis of trichloroethylene metabolism in male B6C3F1 mice: Formation and disposition of trichloroacetic acid, dichloroacetic acid, S-(1,2-dichlorovinyl)glutathione and S-(1,2-dichlorovinyl)-L-cysteine. Toxicol Appl Pharmacol. 2009; 238:90-99. [PubMed: 19409406]

[35]. Kim S, Collins LB, Boysen G, Swenberg JA, Gold A, Ball LM, Bradford BU, Rusyn I. Liquid chromatography electrospray ionization tandem mass spectrometry analysis method for simultaneous detection of trichloroacetic acid, dichloroacetic acid, S-(1,2dichlorovinyl)glutathione and S-(1,2-dichlorovinyl)-L-cysteine. Toxicology. 2009; 262:230-238. [PubMed: 19549554] 
[36]. Merdink JL, Gonzalez-Leon A, Bull RJ, Schultz IR. The extent of dichloroacetate formation from trichloroethylene, chloral hydrate, trichloroacetate, and trichloroethanol in $\mathrm{B} 6 \mathrm{C} 3 \mathrm{~F} 1$ mice. Toxicol Sci. 1998; 45:33-41. [PubMed: 9848108]

[37]. Larson JL, Bull RJ. Species differences in the metabolism of trichloroethylene to the carcinogenic metabolites trichloroacetate and dichloroacetate. Toxicol Appl Pharmacol. 1992; 115:278-285. [PubMed: 1641861]

[38]. Cornett R, James MO, Henderson GN, Cheung J, Shroads AL, Stacpoole PW. Inhibition of glutathione S-transferase zeta and tyrosine metabolism by dichloroacetate: a potential unifying mechanism for its altered biotransformation and toxicity. Biochem Biophys Res Commun. 1999; 262:752-756. [PubMed: 10471397]

[39]. James MO, Yan Z, Cornett R, Jayanti VM, Henderson GN, Davydova N, Katovich MJ, Pollock $\mathrm{B}$, Stacpoole PW. Pharmacokinetics and metabolism of $\left[{ }^{14} \mathrm{C}\right]$ dichloroacetate in male SpragueDawley rats. Identification of glycine conjugates, including hippurate, as urinary metabolites of dichloroacetate. Drug Metab Dispos. 1998; 26:1134-1143. [PubMed: 9806957]

[40]. Tong Z, Board PG, Anders MW. Glutathione transferase zeta catalyses the oxygenation of the carcinogen dichloroacetic acid to glyoxylic acid. Biochem J. 1998; 331(Pt 2):371-374. [PubMed: 9531472]

[41]. Shroads AL, Guo X, Dixit V, Liu HP, James MO, Stacpoole PW. Age-dependent kinetics and metabolism of dichloroacetate: possible relevance to toxicity. J Pharmacol Exp Ther. 2008; 324:1163-1171. [PubMed: 18096758]

[42]. Lipscomb JC, Mahle DA, Brashear WT, Barton HA. Dichloroacetic acid: metabolism in cytosol. Drug Metab Dispos. 1995; 23:1202-1205. [PubMed: 8591719]

[43]. James MO, Cornett R, Yan Z, Henderson GN, Stacpoole PW. Glutathione-dependent conversion to glyoxylate, a major pathway of dichloroacetate biotransformation in hepatic cytosol from humans and rats, is reduced in dichloroacetate-treated rats. Drug Metab Dispos. 1997; 25:12231227. [PubMed: 9351896]

[44]. Dekant W, Metzler M, Henschler D. Novel metabolites of trichloroethylene through dechlorination reactions in rats, mice and humans. Biochem Pharmacol. 1984; 33:2021-2027. [PubMed: 6743352]

[45]. Nakajima T, Wang RS, Elovaara E, Park SS, Gelboin HV, Vainio H. Cytochrome P450-related differences between rats and mice in the metabolism of benzene, toluene, and trichloroethylene in liver microsomes. Biochemical Pharmacology. 1993; 45:1079-1085. [PubMed: 8461037]

[46]. Guengerich FP, Kim DH, Iwasaki M. Role of human cytochrome P-450 IIE1 in the oxidation of many low molecular weight cancer suspects. Chemical Research in Toxicology. 1991; 4:168179. [PubMed: 1664256]

[47]. Nakajima T, Wang RS, Elovaara E, Park SS, Gelboin HV, Vainio H. A comparative study on the contribution of cytochrome P450 isozymes to metabolism of benzene, toluene and trichloroethylene in rat liver. Biochemical Pharmacology. 1992; 43:251-257. [PubMed: 1739413]

[48]. Koop DR, Crump BL, Nordblom GD, Coon MJ. Immunochemical evidence for induction of the alcohol-oxidizing cytochrome P-450 of rabbit liver microsomes by diverse agents: ethanol, imidazole, trichloroethylene, acetone, pyrazole, and isoniazid. Proc Natl Acad Sci U S A. 1985; 82:4065-4069. [PubMed: 3858864]

[49]. Kim D, Ghanayem BI. Comparative metabolism and disposition of trichloroethylene in Cyp2e1-/-and wild-type mice. Drug Metab Dispos. 2006; 34:2020-2027. [PubMed: 16959879]

[50]. Elfarra AA, Krause RJ, Last AR, Lash LH, Parker JC. Species- and sex-related differences in metabolism of trichloroethylene to yield chloral and trichloroethanol in mouse, rat, and human liver microsomes. Drug Metab Dispos. 1998; 26:779-785. [PubMed: 9698293]

[51]. Prout MS, Provan WM, Green T. Species differences in response to trichloroethylene. I. Pharmacokinetics in rats and mice. Toxicol Appl Pharmacol. 1985; 79:389-400. [PubMed: 4035686]

[52]. Green T, Prout MS. Species differences in response to trichloroethylene. II. Biotransformation in rats and mice. Toxicol Appl Pharmacol. 1985; 79:401-411. [PubMed: 3929429] 
[53]. Lash LH, Putt DA, Parker JC. Metabolism and tissue distribution of orally administered trichloroethylene in male and female rats: identification of glutathione- and cytochrome P-450derived metabolites in liver, kidney, blood, and urine. J Toxicol Environ Health A. 2006; 69:1285-1309. [PubMed: 16754541]

[54]. Stenner RD, Merdink JL, Stevens DK, Springer DL, Bull RJ. Enterohepatic recirculation of trichloroethanol glucuronide as a significant source of trichloroacetic acid. Metabolites of trichloroethylene. Drug Metab Dispos. 1997; 25:529-535. [PubMed: 9152590]

[55]. Lipscomb JC, Teuschler LK, Swartout J, Popken D, Cox T, Kedderis GL. The impact of cytochrome P450 2E1-dependent metabolic variance on a risk-relevant pharmacokinetic outcome in humans. Risk Anal. 2003; 23:1221-1238. [PubMed: 14641897]

[56]. Bradford BU, Lock EF, Kosyk O, Kim S, Uehara T, Harbourt D, DeSimone M, Threadgill DW, Tryndyak V, Pogribny IP, Bleyle L, Koop DR, Rusyn I. Interstrain differences in the liver effects of trichloroethylene in a multistrain panel of inbred mice. Toxicol Sci. 2011; 120:206-217. [PubMed: 21135412]

[57]. Lash LH, Putt DA, Huang P, Hueni SE, Parker JC. Modulation of hepatic and renal metabolism and toxicity of trichloroethylene and perchloroethylene by alterations in status of cytochrome P450 and glutathione. Toxicology. 2007; 235:11-26. [PubMed: 17433522]

[58]. Chiu WA, Micallef S, Monster AC, Bois FY. Toxicokinetics of inhaled trichloroethylene and tetrachloroethylene in humans at $1 \mathrm{ppm}$ : empirical results and comparisons with previous studies. Toxicol Sci. 2007; 95:23-36. [PubMed: 17032701]

[59]. Fisher JW, Mahle D, Abbas R. A human physiologically based pharmacokinetic model for trichloroethylene and its metabolites, trichloroacetic acid and free trichloroethanol. Toxicol Appl Pharmacol. 1998; 152:339-359. [PubMed: 9853003]

[60]. Kimmerle G, Eben A. Metabolism, excretion and toxicology of trichloroethylene after inhalation. 2. Experimental human exposure. Arch Toxikol. 1973; 30:127-138. [PubMed: 4685264]

[61]. Monster AC, Boersma G, Duba WC. Pharmacokinetics of trichloroethylene in volunteers, influence of workload and exposure concentration. Int Arch Occup Environ Health. 1976; 38:87102. [PubMed: 1002309]

[62]. Bernauer U, Birner G, Dekant W, Henschler D. Biotransformation of trichloroethene: dosedependent excretion of 2,2,2-trichloro-metabolites and mercapturic acids in rats and humans after inhalation. Arch Toxicol. 1996; 70:338-346. [PubMed: 8975632]

[63]. Birner G, Vamvakas S, Dekant W, Henschler D. Nephrotoxic and genotoxic N-acetyl-Sdichlorovinyl-L-cysteine is a urinary metabolite after occupational 1,1,2-trichloroethene exposure in humans: implications for the risk of trichloroethene exposure. Environ Health Perspect. 1993; 99:281-284. [PubMed: 8319644]

[64]. Hissink EM, Bogaards JJ, Freidig AP, Commandeur JN, Vermeulen NP, van Bladeren PJ. The use of in vitro metabolic parameters and physiologically based pharmacokinetic (PBPK) modeling to explore the risk assessment of trichloroethylene. Environ Toxicol Pharmacol. 2002; 11:259-271. [PubMed: 21782610]

[65]. Sasso AF, Schlosser PM, Kedderis GL, Genter MB, Snawder JE, Li Z, Rieth S, Lipscomb JC. Application of an updated physiologically based pharmacokinetic model for chloroform to evaluate CYP2E1-mediated renal toxicity in rats and mice. Toxicol Sci. 2013; 131:360-374. [PubMed: 23143927]

[66]. Cummings BS, Lasker JM, Lash LH. Expression of glutathione-dependent enzymes and cytochrome P450s in freshly isolated and primary cultures of proximal tubular cells from human kidney. J Pharmacol Exp Ther. 2000; 293:677-685. [PubMed: 10773044]

[67]. Amet Y, Berthou F, Fournier G, Dreano Y, Bardou L, Cledes J, Menez JF. Cytochrome P450 4A and 2E1 expression in human kidney microsomes. Biochem Pharmacol. 1997; 53:765-771. [PubMed: 9113097]

[68]. Cummings BS, Zangar RC, Novak RF, Lash LH. Cellular distribution of cytochromes P-450 in the rat kidney. Drug Metab Dispos. 1999; 27:542-548. [PubMed: 10101150]

[69]. Lipscomb JC, Fisher JW, Confer PD, Byczkowski JZ. In vitro to in vivo extrapolation for trichloroethylene metabolism in humans. Toxicol Appl Pharmacol. 1998; 152:376-387. [PubMed: 9853006] 
[70]. Chiu WA, Okino MS, Evans MV. Characterizing uncertainty and population variability in the toxicokinetics of trichloroethylene and metabolites in mice, rats, and humans using an updated database, physiologically based pharmacokinetic (PBPK) model, and Bayesian approach. Toxicol Appl Pharmacol. 2009; 241:36-60. [PubMed: 19660485]

[71]. Banerjee S, Van Duuren BL. Covalent binding of the carcinogen trichloroethylene to hepatic microsomal proteins and to exogenous DNA in vitro. Cancer Res. 1978; 38:776-780. [PubMed: 626981]

[72]. Van Duuren BL, Banerjee S. Covalent interaction of metabolites of the carcinogen trichloroethylene in rat hepatic microsomes. Cancer Res. 1976; 36:2419-2422. [PubMed: 1277148]

[73]. Chang LW, Daniel FB, DeAngelo AB. Analysis of DNA strand breaks induced in rodent liver in vivo, hepatocytes in primary culture, and a human cell line by chlorinated acetic acids and chlorinated acetaldehydes. Environ Mol Mutagen. 1992; 20:277-288. [PubMed: 1330547]

[74]. Leavitt SA, DeAngelo AB, George MH, Ross JA. Assessment of the mutagenicity of dichloroacetic acid in lacI transgenic B6C3F1 mouse liver. Carcinogenesis. 1997; 18:2101-2106. [PubMed: 9395208]

[75]. Ferreira-Gonzalez A, Deangelo AB, Nasim S, Garrett CT. Ras oncogene activation during hepatocarcinogenesis in $\mathrm{B} 6 \mathrm{C} 3 \mathrm{~F} 1$ male mice by dichloroacetic and trichloroacetic acids. Carcinogenesis. 1995; 16:495-500. [PubMed: 7697804]

[76]. Rusyn I, Chiu WA, Lash LH, Kromhout H, Hansen J, Guyton KZ. Trichloroethylene: Mechanistic, epidemiologic and other supporting evidence of carcinogenic hazard. Pharmacol Ther. 2014; 141:55-68. [PubMed: 23973663]

[77]. Ikbal M, Tastekin A, Dogan H, Pirim I, Ors R. The assessment of genotoxic effects in lymphocyte cultures of infants treated with chloral hydrate. Mutat Res. 2004; 564:159-164. [PubMed: 15507380]

[78]. Plewa MJ, Kargalioglu Y, Vankerk D, Minear RA, Wagner ED. Mammalian cell cytotoxicity and genotoxicity analysis of drinking water disinfection by-products. Environ Mol Mutagen. 2002; 40:134-142. [PubMed: 12203407]

[79]. Kargalioglu Y, McMillan BJ, Minear RA, Plewa MJ. Analysis of the cytotoxicity and mutagenicity of drinking water disinfection by-products in Salmonella typhimurium. Teratog Carcinog Mutagen. 2002; 22:113-128. [PubMed: 11835289]

[80]. DeMarini DM, Perry E, Shelton ML. Dichloroacetic acid and related compounds: induction of prophage in E. coli and mutagenicity and mutation spectra in Salmonella TA100. Mutagenesis. 1994; 9:429-437. [PubMed: 7837977]

[81]. Mackay JM, Fox V, Griffiths K, Fox DA, Howard CA, Coutts C, Wyatt I, Styles JA. Trichloroacetic acid: investigation into the mechanism of chromosomal damage in the in vitro human lymphocyte cytogenetic assay and the mouse bone marrow micronucleus test. Carcinogenesis. 1995; 16:1127-1133. [PubMed: 7767975]

[82]. Harrington-Brock K, Doerr CL, Moore MM. Mutagenicity of three disinfection by-products: diand trichloroacetic acid and chloral hydrate in L5178Y/TK +/- (-)3.7.2C mouse lymphoma cells. Mutat Res. 1998; 413:265-276. [PubMed: 9651541]

[83]. Zhang SH, Miao DY, Liu AL, Zhang L, Wei W, Xie H, Lu WQ. Assessment of the cytotoxicity and genotoxicity of haloacetic acids using microplate-based cytotoxicity test and CHO/HGPRT gene mutation assay. Mutat Res. 2010; 703:174-179. [PubMed: 20801231]

[84]. Nelson MA, Lansing AJ, Sanchez IM, Bull RJ, Springer DL. Dichloroacetic acid and trichloroacetic acid-induced DNA strand breaks are independent of peroxisome proliferation. Toxicology. 1989; 58:239-248. [PubMed: 2799828]

[85]. Styles JA, Wyatt I, Coutts C. Trichloroacetic acid: studies on uptake and effects on hepatic DNA and liver growth in mouse. Carcinogenesis. 1991; 12:1715-1719. [PubMed: 1893532]

[86]. Bull RJ, Orner GA, Cheng RS, Stillwell L, Stauber AJ, Sasser LB, Lingohr MK, Thrall BD. Contribution of dichloroacetate and trichloroacetate to liver tumor induction in mice by trichloroethylene. Toxicol Appl Pharmacol. 2002; 182:55-65. [PubMed: 12127263] 
[87]. Beland FA. NTP technical report on the toxicity and metabolism studies of chloral hydrate (CAS No. 302-17-0). Administered by gavage to F344/N rats and B6C3F1 mice. Toxic Rep Ser. 1999:1-66. A61-E67. [PubMed: 11803702]

[88]. Waskell L. A study of the mutagenicity of anesthetics and their metabolites. Mutat Res. 1978; 57:141-153. [PubMed: 351387]

[89]. Dourado DF, Fernandes PA, Ramos MJ. Mammalian cytosolic glutathione transferases. Curr Protein Pept Sci. 2008; 9:325-337. [PubMed: 18691123]

[90]. Bruning T, Vamvakas S, Makropoulos V, Birner G. Acute intoxication with trichloroethene: clinical symptoms, toxicokinetics, metabolism, and development of biochemical parameters for renal damage. Toxicol Sci. 1998; 41:157-165. [PubMed: 9520351]

[91]. Lash LH, Qian W, Putt DA, Jacobs K, Elfarra AA, Krause RJ, Parker JC. Glutathione conjugation of trichloroethylene in rats and mice: sex-, species-, and tissue-dependent differences. Drug Metab Dispos. 1998; 26:12-19. [PubMed: 9443846]

[92]. Lash LH, Xu Y, Elfarra AA, Duescher RJ, Parker JC. Glutathione-dependent metabolism of trichloroethylene in isolated liver and kidney cells of rats and its role in mitochondrial and cellular toxicity. Drug Metab Dispos. 1995; 23:846-853. [PubMed: 7493552]

[93]. Lash LH, Anders MW. Cytotoxicity of S-(1,2-dichlorovinyl)glutathione and S-(1,2dichlorovinyl)-L-cysteine in isolated rat kidney cells. J Biol Chem. 1986; 261:13076-13081. [PubMed: 2875994]

[94]. McKinney LL, Picken JC, Weakley FB, Eldridge AC, Campbell RE, Cowan JC, Biester HE. Possible toxic factor of trichloroethylene-extracted soybean oil mea. Journal of the American Chemical Society. 1959; 81:909-915.

[95]. Lock EA, Sani Y, Moore RB, Finkelstein MB, Anders MW, Seawright AA. Bone marrow and renal injury associated with haloalkene cysteine conjugates in calves. Arch Toxicol. 1996; 70:607-619. [PubMed: 8870953]

[96]. Birner G, Bernauer U, Werner M, Dekant W. Biotransformation, excretion and nephrotoxicity of haloalkene-derived cysteine S-conjugates. Arch Toxicol. 1997; 72:1-8. [PubMed: 9458184]

[97]. Green T, Dow J, Ellis MK, Foster JR, Odum J. The role of glutathione conjugation in the development of kidney tumours in rats exposed to trichloroethylene. Chem Biol.Interact. 1997; 105:99-117. [PubMed: 9251723]

[98]. Uttamsingh V, Anders MW. Acylase-catalyzed deacetylation of haloalkene-derived mercapturates. Chem Res Toxicol. 1999; 12:937-942. [PubMed: 10525269]

[99]. Uttamsingh V, Baggs RB, Krenitsky DM, Anders MW. Immunohistochemical localization of the acylases that catalyze the deacetylation of $\mathrm{N}$-acetyl-L-cysteine and haloalkene-derived mercapturates. Drug Metab Dispos. 2000; 28:625-632. [PubMed: 10820133]

[100]. Newman D, Abuladze N, Scholz K, Dekant W, Tsuprun V, Ryazantsev S, Bondar G, Sassani P, Kurtz I, Pushkin A. Specificity of aminoacylase III-mediated deacetylation of mercapturic acids. Drug Metab Dispos. 2007; 35:43-50. [PubMed: 17012540]

[101]. Werner M, Birner G, Dekant W. Sulfoxidation of mercapturic acids derived from tri- and tetrachloroethene by cytochromes P450 3A: A bioactivation reaction in addition to deacetylation and cysteine conjugate á - lyase mediated cleavage. Chemical Research in Toxicology. 1996; 9:41-49. [PubMed: 8924615]

[102]. Werner M, Guo Z, Birner G, Dekant W, Guengerich FP. The sulfoxidation of the hexachlorobutadiene metabolite $\mathrm{N}$-acetyl-S-(1,2,3,4,4-pentachlorobutadienyl)-L-cysteine is catalyzed by human cytochrome P450 3A enzymes. Chem Res Toxicol. 1995; 8:917-923. [PubMed: 8555406]

[103]. Werner M, Birner G, Dekant W. The role of cytochrome P4503A1/2 in the sex-specific sulfoxidation of the hexachlorobutadiene metabolite, N-acetyl-S-(pentachlorobutadienyl)-Lcysteine in rats. Drug Metab Dispos. 1995; 23:861-868. [PubMed: 7493554]

[104]. Volkel W, Dekant W. Chlorothioketene, the ultimate reactive intermediate formed by cysteine conjugate beta-lyase-mediated cleavage of the trichloroethene metabolite S-(1,2-Dichlorovinyl)L-cysteine, forms cytosine adducts in organic solvents, but not in aqueous solution. Chem Res Toxicol. 1998; 11:1082-1088. [PubMed: 9760283] 
[105]. Dekant W, Berthold K, Vamvakas S, Henschler D, Anders MW. Thioacylating intermediates as metabolites of S-(1,2-dichlorovinyl)-L-cysteine and S-(1,2,2-trichlorovinyl)-L-cysteine formed by cysteine conjugate beta-lyase. Chem Res Toxicol. 1988; 1:175-178. [PubMed: 2979728]

[106]. Muller M, Birner G, Sander M, Dekant W. Reactivity of haloketenes and halothioketenes with nucleobases: reactions in vitro with DNA. Chemical Research in Toxicology. 1998; 11:464-470. [PubMed: 9585477]

[107]. Hayden PJ, Ichimura T, McCann DJ, Pohl LR, Stevens JL. Detection of cysteine conjugate metabolite adduct formation with specific mitochondrial proteins using antibodies raised against halothane metabolite adducts. J Biol Chem. 1991; 266:18415-18418. [PubMed: 1917965]

[108]. Hayden PJ, Welsh CJ, Yang Y, Schaefer WH, Ward AJ, Stevens JL. Formation of mitochondrial phospholipid adducts by nephrotoxic cysteine conjugate metabolites. Chem Res Toxicol. 1992; 5:232-237. [PubMed: 1643252]

[109]. Lash LH. Glutathione-dependent bioactivation. Curr Protoc Toxicol. 2007; 34:7.9.1-7.9.16.

[110]. Elfarra AA, Lash LH, Anders MW. Alpha-ketoacids stimulate rat renal cysteine conjugate betalyase activity and potentiate the cytotoxicity of S-(1,2-dichlorovinyl)-L-cysteine. Mol Pharmacol. 1987; 31:208-212. [PubMed: 3807895]

[111]. Stevens JL, Robbins JD, Byrd RA. A purified cysteine conjugate beta-lyase from rat kidney cytosol. Requirement for an alpha-keto acid or an amino acid oxidase for activity and identity with soluble glutamine transaminase K. J Biol Chem. 1986; 261:15529-15537. [PubMed: 3782077]

[112]. Cooper AJ, Krasnikov BF, Niatsetskaya ZV, Pinto JT, Callery PS, Villar MT, Artigues A, Bruschi SA. Cysteine S-conjugate beta-lyases: important roles in the metabolism of naturally occurring sulfur and selenium-containing compounds, xenobiotics and anticancer agents. Amino Acids. 2011; 41:7-27. [PubMed: 20306345]

[113]. Cooper AJ, Pinto JT. Cysteine S-conjugate beta-lyases. Amino Acids. 2006; 30:1-15. [PubMed: 16463021]

[114]. Ripp SL, Overby LH, Philpot RM, Elfarra AA. Oxidation of cysteine S-conjugates by rabbit liver microsomes and cDNA-expressed flavin-containing mono-oxygenases: studies with S-(1,2dichlorovinyl)-L-cysteine, S-(1,2,2-trichlorovinyl)-L-cysteine, S-allyl-L-cysteine, and S-benzylL-cysteine. Molecular Pharmacology. 1997; 51:507-515. [PubMed: 9058607]

[115]. Krueger SK, Williams DE. Mammalian flavin-containing monooxygenases: structure/function, genetic polymorphisms and role in drug metabolism. Pharmacol Ther. 2005; 106:357-387. [PubMed: 15922018]

[116]. Nelson DR, Zeldin DC, Hoffman SM, Maltais LJ, Wain HM, Nebert DW. Comparison of cytochrome P450 (CYP) genes from the mouse and human genomes, including nomenclature recommendations for genes, pseudogenes and alternative-splice variants. Pharmacogenetics. 2004; 14:1-18. [PubMed: 15128046]

[117]. Cashman JR, Zhang J. Human flavin-containing monooxygenases. Annu Rev Pharmacol Toxicol. 2006; 46:65-100. [PubMed: 16402899]

[118]. Dekant W, Metzler M, Henschler D. Identification of S-1,2-dichlorovinyl-N-acetyl-cysteine as a urinary metabolite of trichloroethylene: a possible explanation for its nephrocarcinogenicity in male rats. Biochem Pharmacol. 1986; 35:2455-2458. [PubMed: 3741453]

[119]. Commandeur JN, Vermeulen NP. Identification of N-acetyl(2,2-dichlorovinyl)- and Nacetyl(1,2-dichlorovinyl)-L-cysteine as two regioisomeric mercapturic acids of trichloroethylene in the rat. Chem Res Toxicol. 1990; 3:212-218. [PubMed: 1966701]

[120]. Lash LH, Putt DA, Brashear WT, Abbas R, Parker JC, Fisher JW. Identification of S-(1,2dichlorovinyl)glutathione in the blood of human volunteers exposed to trichloroethylene. $\mathrm{J}$ Toxicol Environ Health A. 1999; 56:1-21. [PubMed: 9923751]

[121]. Cummings BS, Parker JC, Lash LH. Role of cytochrome P450 and glutathione S-transferase alpha in the metabolism and cytotoxicity of trichloroethylene in rat kidney. Biochem Pharmacol. 2000; 59:531-543. [PubMed: 10660119]

[122]. Goeptar AR, Commandeur JN, Van Ommen B, van Bladeren PJ, Vermeulen NP. Metabolism and kinetics of trichloroethylene in relation to toxicity and carcinogenicity. Relevance of the mercapturic acid pathway. Chem Res Toxicol. 1995; 8:3-21. [PubMed: 7703363] 
[123]. Lash LH, Nelson RM, Van Dyke RA, Anders MW. Purification and characterization of human kidney cytosolic cysteine conjugate beta-lyase activity. Drug Metab Dispos. 1990; 18:50-54. [PubMed: 2139845]

[124]. McGoldrick TA, Lock EA, Rodilla V, Hawksworth GM. Renal cysteine conjugate C-S lyase mediated toxicity of halogenated alkenes in primary cultures of human and rat proximal tubular cells. Arch Toxicol. 2003; 77:365-370. [PubMed: 12700887]

[125]. Cooper AJ, Pinto JT, Krasnikov BF, Niatsetskaya ZV, Han Q, Li J, Vauzour D, Spencer JP. Substrate specificity of human glutamine transaminase $\mathrm{K}$ as an aminotransferase and as a cysteine S-conjugate beta-lyase. Arch Biochem Biophys. 2008; 474:72-81. [PubMed: 18342615]

[126]. Lash LH, Elfarra AA, Anders MW. Renal cysteine conjugate beta-lyase. Bioactivation of nephrotoxic cysteine S-conjugates in mitochondrial outer membrane. J Biol Chem. 1986; 261:5930-5935. [PubMed: 3700378]

[127]. Stevens JL, Ayoubi N, Robbins JD. The role of mitochondrial matrix enzymes in the metabolism and toxicity of cysteine conjugates. J Biol Chem. 1988; 263:3395-3401. [PubMed: 3343250]

[128]. Yamauchi A, Stijntjes GJ, Commandeur JN, Vermeulen NP. Purification of glutamine transaminase K/cysteine conjugate beta-lyase from rat renal cytosol based on hydrophobic interaction HPLC and gel permeation FPLC. Protein Expr Purif. 1993; 4:552-562. [PubMed: 8286953]

[129]. Abraham DG, Cooper AJ. Cloning and expression of a rat kidney cytosolic glutamine transaminase $\mathrm{K}$ that has strong sequence homology to kynurenine pyruvate aminotransferase. Arch Biochem Biophys. 1996; 335:311-320. [PubMed: 8914928]

[130]. Cooper AJ, Abraham DG, Gelbard AS, Lai JC, Petito CK. High activities of glutamine transaminase $\mathrm{K}$ (dichlorovinylcysteine beta-lyase) and omega-amidase in the choroid plexus of rat brain. J Neurochem. 1993; 61:1731-1741. [PubMed: 8228989]

[131]. Perry SJ, Schofield MA, MacFarlane M, Lock EA, King LJ, Gibson GG, Goldfarb PS. Isolation and expression of a cDNA coding for rat kidney cytosolic cysteine conjugate beta-lyase. Mol Pharmacol. 1993; 43:660-665. [PubMed: 8502223]

[132]. Cooper AJ, Wang J, Gartner CA, Bruschi SA. Co-purification of mitochondrial HSP70 and mature protein disulfide isomerase with a functional rat kidney high-M(r) cysteine S-conjugate beta-lyase. Biochem Pharmacol. 2001; 62:1345-1353. [PubMed: 11709194]

[133]. Cooper AJ, Bruschi SA, Iriarte A, Martinez-Carrion M. Mitochondrial aspartate aminotransferase catalyses cysteine S-conjugate beta-lyase reactions. Biochem J. 2002; 368:253261. [PubMed: 12137566]

[134]. Cooper AJ, Bruschi SA, Conway M, Hutson SM. Human mitochondrial and cytosolic branchedchain aminotransferases are cysteine S-conjugate beta-lyases, but turnover leads to inactivation. Biochem Pharmacol. 2003; 65:181-192. [PubMed: 12504794]

[135]. Malherbe P, Alberati-Giani D, Kohler C, Cesura AM. Identification of a mitochondrial form of kynurenine aminotransferase/glutamine transaminase K from rat brain. FEBS Lett. 1995; 367:141-144. [PubMed: 7796908]

[136]. Novick RM, Elfarra AA. Purification and characterization of flavin-containing monooxygenase isoform 3 from rat kidney microsomes. Drug Metab Dispos. 2008; 36:2468-2474. [PubMed: 18775983]

[137]. Sausen PJ, Duescher RJ, Elfarra AA. Further characterization and purification of the flavindependent S-benzyl-L-cysteine S-oxidase activities of rat liver and kidney microsomes. Mol Pharmacol. 1993; 43:388-396. [PubMed: 8450833]

[138]. Sausen PJ, Elfarra AA. Reactivity of cysteine S-conjugate sulfoxides: formation of S-[1chloro-2-(S-glutathionyl)vinyl]-L-cysteine sulfoxide by the reaction of S-(1,2-dichlorovinyl)-Lcysteine sulfoxide with glutathione. Chem Res Toxicol. 1991; 4:655-660. [PubMed: 1807449]

[139]. Sausen PJ, Elfarra AA. Cysteine conjugate S-oxidase. Characterization of a novel enzymatic activity in rat hepatic and renal microsomes. J Biol Chem. 1990; 265:6139-6145. [PubMed: 2318851]

[140]. Bloemen LJ, Monster AC, Kezic S, Commandeur JN, Veulemans H, Vermeulen NP, Wilmer JW. Study on the cytochrome P-450- and glutathione-dependent biotransformation of 
trichloroethylene in humans. Int.Arch Occup.Environ.Health. 2001; 74:102-108. [PubMed: 11317702]

[141]. Lash LH. Renal membrane transport of glutathione in toxicology and disease. Vet Pathol. 2011; 48:408-419. [PubMed: 20656901]

[142]. Lash LH. Role of glutathione transport processes in kidney function. Toxicol Appl Pharmacol. 2005; 204:329-342. [PubMed: 15845422]

[143]. Lash LH, Lipscomb JC, Putt DA, Parker JC. Glutathione conjugation of trichloroethylene in human liver and kidney: kinetics and individual variation. Drug Metab Dispos. 1999; 27:351359. [PubMed: 10064565]

[144]. Rodilla V, Benzie AA, Veitch JM, Murray GI, Rowe JD, Hawksworth GM. Glutathione Stransferases in human renal cortex and neoplastic tissue: enzymatic activity, isoenzyme profile and immunohistochemical localization. Xenobiotica. 1998; 28:443-456. [PubMed: 9622847]

[145]. Campbell JA, Corrigall AV, Guy A, Kirsch RE. Immunohistologic localization of alpha, mu, and pi class glutathione S-transferases in human tissues. Cancer. 1991; 67:1608-1613. [PubMed: 2001549]

[146]. Hiley CG, Otter M, Bell J, Strange RC, Keeling JW. Immunocytochemical studies of the distribution of alpha and pi isoforms of glutathione S-transferase in cystic renal diseases. Pediatr Pathol. 1994; 14:497-504. [PubMed: 8066005]

[147]. Terrier P, Townsend AJ, Coindre JM, Triche TJ, Cowan KH. An immunohistochemical study of pi class glutathione S-transferase expression in normal human tissue. Am J Pathol. 1990; 137:845-853. [PubMed: 1977319]

[148]. Ginsberg G, Smolenski S, Hattis D, Guyton KZ, Johns DO, Sonawane B. Genetic Polymorphism in Glutathione Transferases (GST): Population distribution of GSTM1, T1, and P1 conjugating activity. J Toxicol Environ Health B Crit Rev. 2009; 12:389-439. [PubMed: 20183528]

[149]. Hinchman CA, Ballatori N. Glutathione-degrading capacities of liver and kidney in different species. Biochem Pharmacol. 1990; 40:1131-1135. [PubMed: 1975172]

[150]. McCarthy RI, Lock EA, Hawksworth GM. Cytosolic C-S lyase activity in human kidney samples-relevance for the nephrotoxicity of halogenated alkenes in man. Toxicol Ind Health. 1994; 10:103-112. [PubMed: 7570611]

[151]. Perry S, Harries H, Scholfield C, Lock T, King L, Gibson G, Goldfarb P. Molecular cloning and expression of a cDNA for human kidney cysteine conjugate beta-lyase. FEBS Lett. 1995; 360:277-280. [PubMed: 7883047]

[152]. Krause RJ, Lash LH, Elfarra AA. Human kidney flavin-containing monooxygenases and their potential roles in cysteine s-conjugate metabolism and nephrotoxicity. J Pharmacol Exp Ther. 2003; 304:185-191. [PubMed: 12490590]

[153]. Vamvakas S, Elfarra AA, Dekant W, Henschler D, Anders MW. Mutagenicity of amino acid and glutathione S-conjugates in the Ames test. Mutat Res. 1988; 206:83-90. [PubMed: 2901035]

[154]. Dekant W, Vamvakas S, Berthold K, Schmidt S, Wild D, Henschler D. Bacterial beta-lyase mediated cleavage and mutagenicity of cysteine conjugates derived from the nephrocarcinogenic alkenes trichloroethylene, tetrachloroethylene and hexachlorobutadiene. Chem Biol Interact. 1986; 60:31-45. [PubMed: 3536138]

[155]. Vamvakas S, Berthold K, Dekant W, Henschler D. Bacterial cysteine conjugate beta-lyase and the metabolism of cysteine S-conjugates: structural requirements for the cleavage of S-conjugates and the formation of reactive intermediates. Chem Biol Interact. 1988; 65:59-71. [PubMed: 3278814]

[156]. Irving RM, Elfarra AA. Mutagenicity of the cysteine S-conjugate sulfoxides of trichloroethylene and tetrachloroethylene in the Ames test. Toxicology. 2013; 306:157-161. [PubMed: 23416178]

[157]. Vamvakas S, Dekant W, Schiffmann D, Henschler D. Induction of unscheduled DNA synthesis and micronucleus formation in Syrian hamster embryo fibroblasts treated with cysteine $\mathrm{S}$ conjugates of chlorinated hydrocarbons. Cell Biol Toxicol. 1988; 4:393-403. [PubMed: 3228710] 
[158]. Vamvakas S, Dekant W, Henschler D. Assessment of unscheduled DNA synthesis in a cultured line of renal epithelial cells exposed to cysteine S-conjugates of haloalkenes and haloalkanes. Mutat Res. 1989; 222:329-335. [PubMed: 2704384]

[159]. Vamvakas S, Richter H, Bittner D. Induction of dedifferentiated clones of LLC-PK1 cells upon long-term exposure to dichlorovinylcysteine. Toxicology. 1996; 106:65-74. [PubMed: 8571403]

[160]. Mally A, Walker CL, Everitt JI, Dekant W, Vamvakas S. Analysis of renal cell transformation following exposure to trichloroethene in vivo and its metabolite S-(dichlorovinyl)-L-cysteine in vitro. Toxicology. 2006; 224:108-118. [PubMed: 16730402]

[161]. Jaffe DR, Hassall CD, Gandolfi AJ, Brendel K. Production of DNA single strand breaks in rabbit renal tissue after exposure to 1,2-dichlorovinylcysteine. Toxicology. 1985; 35:25-33. [PubMed: 4002236]

[162]. Clay P. Assessment of the genotoxicity of trichloroethylene and its metabolite, S-(1,2dichlorovinyl)-L-cysteine (DCVC), in the comet assay in rat kidney. Mutagenesis. 2008; 23:2733. [PubMed: 18003627]

[163]. Lash LH, Jones DP. Renal glutathione transport. Characteristics of the sodium-dependent system in the basal-lateral membrane. J Biol Chem. 1984; 259:14508-14514. [PubMed: 6501304]

[164]. Lash LH, Jones DP. Transport of glutathione by renal basal-lateral membrane vesicles. Biochem Biophys Res Commun. 1983; 112:55-60. [PubMed: 6838619]

[165]. Lash LH, Jones DP. Uptake of the glutathione conjugate S-(1,2-dichlorovinyl)glutathione by renal basal-lateral membrane vesicles and isolated kidney cells. Mol Pharmacol. 1985; 28:278282. [PubMed: 3839897]

[166]. Lash LH, Putt DA, Xu F, Matherly LH. Role of rat organic anion transporter 3 (Oat3) in the renal basolateral transport of glutathione. Chem Biol Interact. 2007; 170:124-134. [PubMed: 17719021]

[167]. Lipscomb JC, Garrett CM, Snawder JE. Cytochrome P450-dependent metabolism of trichloroethylene: interindividual differences in humans. Toxicol Appl Pharmacol. 1997; 142:311-318. [PubMed: 9070354]

[168]. Ginsberg G, Guyton K, Johns D, Schimek J, Angle K, Sonawane B. Genetic polymorphism in metabolism and host defense enzymes: implications for human health risk assessment. Crit Rev Toxicol. 2010; 40:575-619. [PubMed: 20662711]

[169]. Boccia S, De Lauretis A, Gianfagna F, van Duijn CM, Ricciardi G. CYP2E1PstI/RsaI polymorphism and interaction with tobacco, alcohol and GSTs in gastric cancer susceptibility: A meta-analysis of the literature. Carcinogenesis. 2007; 28:101-106. [PubMed: 16837478]

[170]. McCarver DG, Byun R, Hines RN, Hichme M, Wegenek W. A genetic polymorphism in the regulatory sequences of human CYP2E1: association with increased chlorzoxazone hydroxylation in the presence of obesity and ethanol intake. Toxicol Appl Pharmacol. 1998; 152:276-281. [PubMed: 9772223]

[171]. Neafsey P, Ginsberg G, Hattis D, Johns DO, Guyton KZ, Sonawane B. Genetic polymorphism in CYP2E1: Population distribution of CYP2E1 activity. J Toxicol Environ Health B Crit Rev. 2009; 12:362-388. [PubMed: 20183527]

[172]. Bradford BU, Kono H, Isayama F, Kosyk O, Wheeler MD, Akiyama TE, Bleye L, Krausz KW, Gonzalez FJ, Koop DR, Rusyn I. Cytochrome P450 CYP2E1, but not nicotinamide adenine dinucleotide phosphate oxidase, is required for ethanol-induced oxidative DNA damage in rodent liver. Hepatology. 2005; 41:336-344. [PubMed: 15660387]

[173]. Cheng Q, Aleksunes LM, Manautou JE, Cherrington NJ, Scheffer GL, Yamasaki H, Slitt AL. Drug-metabolizing enzyme and transporter expression in a mouse model of diabetes and obesity. Mol Pharm. 2008; 5:77-91. [PubMed: 18189363]

[174]. Erdman AR, Mangravite LM, Urban TJ, Lagpacan LL, Castro RA, de la Cruz M, Chan W, Huang CC, Johns SJ, Kawamoto M, Stryke D, Taylor TR, Carlson EJ, Ferrin TE, Brett CM, Burchard EG, Giacomini KM. The human organic anion transporter 3 (OAT3; SLC22A8): genetic variation and functional genomics. Am J Physiol Renal Physiol. 2006; 290:F905-912. [PubMed: 16291576] 
[175]. Lash LH, Putt DA, Cai H. Membrane transport function in primary cultures of human proximal tubular cells. Toxicology. 2006; 228:200-218. [PubMed: 16997449]

[176]. Urban TJ, Sebro R, Hurowitz EH, Leabman MK, Badagnani I, Lagpacan LL, Risch N, Giacomini KM. Functional genomics of membrane transporters in human populations. Genome Res. 2006; 16:223-230. [PubMed: 16354753]

[177]. Kerb R. Implications of genetic polymorphisms in drug transporters for pharmacotherapy. Cancer Lett. 2006; 234:4-33. [PubMed: 16504381]

[178]. Buist SC, Klaassen CD. Rat and mouse differences in gender-predominant expression of organic anion transporter (Oat1-3; Slc22a6-8) mRNA levels. Drug Metab Dispos. 2004; 32:620 625. [PubMed: 15155553]

[179]. Buist SC, Cherrington NJ, Klaassen CD. Endocrine regulation of rat organic anion transporters. Drug Metab Dispos. 2003; 31:559-564. [PubMed: 12695343]

[180]. Kato Y, Kuge K, Kusuhara H, Meier PJ, Sugiyama Y. Gender difference in the urinary excretion of organic anions in rats. J Pharmacol Exp Ther. 2002; 302:483-489. [PubMed: 12130705]

[181]. Ljubojevic M, Herak-Kramberger CM, Hagos Y, Bahn A, Endou H, Burckhardt G, Sabolic I. Rat renal cortical OAT1 and OAT3 exhibit gender differences determined by both androgen stimulation and estrogen inhibition. Am J Physiol Renal Physiol. 2004; 287:F124-138. [PubMed: 15010355]

[182]. Barros SA, Srimaroeng C, Perry JL, Walden R, Dembla-Rajpal N, Sweet DH, Pritchard JB. Activation of protein kinase Czeta increases OAT1 (SLC22A6)- and OAT3 (SLC22A8)mediated transport. J Biol Chem. 2009; 284:2672-2679. [PubMed: 19028678]

[183]. Sekine T, Miyazaki H, Endou H. Molecular physiology of renal organic anion transporters. Am J Physiol Renal Physiol. 2006; 290:F251-261. [PubMed: 16403838]

[184]. Terada T, Inui K. Gene expression and regulation of drug transporters in the intestine and kidney. Biochem Pharmacol. 2007; 73:440-449. [PubMed: 17137557]

[185]. Brauch H, Weirich G, Klein B, Rabstein S, Bolt HM, Bruning T. VHL mutations in renal cell cancer: does occupational exposure to trichloroethylene make a difference? Toxicol Lett. 2004; 151:301-310. [PubMed: 15177666]

[186]. Bruning T, Weirich G, Hornauer MA, Hofler H, Brauch H. Renal cell carcinomas in trichloroethene (TRI) exposed persons are associated with somatic mutations in the von HippelLindau (VHL) tumour suppressor gene. Arch Toxicol. 1997; 71:332-335. [PubMed: 9137812]

[187]. Charbotel B, Gad S, Caiola D, Beroud C, Fevotte J, Bergeret A, Ferlicot S, Richard S. Trichloroethylene exposure and somatic mutations of the VHL gene in patients with Renal Cell Carcinoma. J Occup Med Toxicol. 2007; 2:13. [PubMed: 17997830]

[188]. Moore LE, Nickerson ML, Brennan P, Toro JR, Jaeger E, Rinsky J, Han SS, Zaridze D, Matveev V, Janout V, Kollarova H, Bencko V, Navratilova M, Szeszenia-Dabrowska N, Mates D, Schmidt LS, Lenz P, Karami S, Linehan WM, Merino M, Chanock S, Boffetta P, Chow WH, Waldman FM, Rothman N. Von Hippel-Lindau (VHL) inactivation in sporadic clear cell renal cancer: associations with germline VHL polymorphisms and etiologic risk factors. PLoS Genet. 2011; 7:e1002312. [PubMed: 22022277]

[189]. Moore LE, Boffetta P, Karami S, Brennan P, Stewart PS, Hung R, Zaridze D, Matveev V, Janout V, Kollarova H, Bencko V, Navratilova M, Szeszenia-Dabrowska N, Mates D, Gromiec J, Holcatova I, Merino M, Chanock S, Chow WH, Rothman N. Occupational trichloroethylene exposure and renal carcinoma risk: evidence of genetic susceptibility by reductive metabolism gene variants. Cancer Res. 2010; 70:6527-6536. [PubMed: 20663906]

[190]. Chiu WA, Campbell JL Jr. Clewell HJ III, Zhou YH, Wright FA, Guyton KZ, Rusyn I. Physiologically based pharmacokinetic (PBPK) modeling of interstrain variability in trichloroethylene metabolism in the mouse. Environ Health Perspec. 2014 doi:10.1289/ehp. 1307623.

[191]. Bove FJ, Ruckart PZ, Maslia M, Larson TC. Evaluation of mortality among marines and navy personnel exposed to contaminated drinking water at USMC base Camp Lejeune: a retrospective cohort study. Environ Health. 2010; 13:10. [PubMed: 24552493] 


\section{Research Highlights}

- Trichloroethylene is mutagenic and carcinogenic in humans and animals

- Trichloroethylene undergoes both cytochrome P450- and glutathione-dependent metabolism

- Glutathione-derived metabolites of trichloroethylene are mutagenic

- Species-, sex-, and tissue-dependent differences exist in trichloroethylene metabolism 


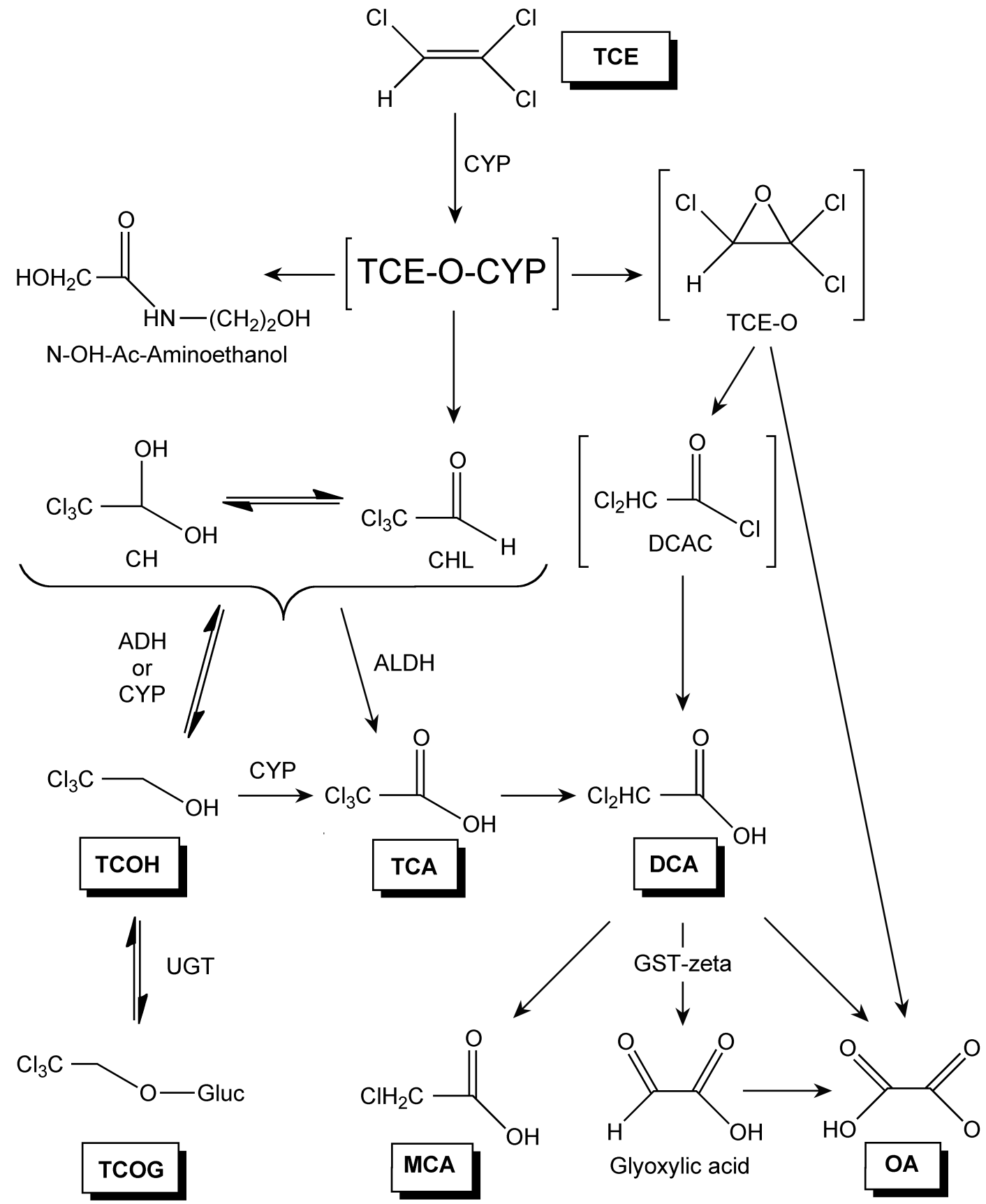

Fig. 1. Scheme for biotransformation of TCE by oxidative metabolism

TCE undergoes cytochrome P450 (CYP)-dependent oxidation to form either a TCE-CYP intermediate or an epoxide intermediate. Further processing through either non-enzymatic rearrangements or actions of aldehyde dehydrogenase (ALDH), alcohol dehydrogenase (ADH), CYPs, or GSH S-transferase zeta (GSTZ) yield a variety of metabolites, including chloral (CHL) and chloral hydrate (CH), dichloroacetate (DCA), trichloroacetate (TCA), trichloroethanol (TCOH) and its glucuronide (TCOG), monochloroacetate (MCA), and oxalate $(\mathrm{OA})$. Names of metabolites that are recovered in urine are shown in boxes and 
those that are chemically unstable or reactive are shown in brackets. Other abbreviations: TCE-O, trichloroethylene oxide; DCAC, dichloroacetyl chloride; N-OH-Ac-Aminoethanol, N-hydroxyacetyl aminoethanol; UGT, UDP-glucuronosyltransferase. 
<smiles>[NH3+]C(CCC(=O)NC(SC(Cl)=CCl)C(=O)NCCC(=O)[O-])C(=O)[O-]</smiles><smiles>[NH3+][C@@H]([18OH])CS/C(Cl)=C\Cl</smiles>

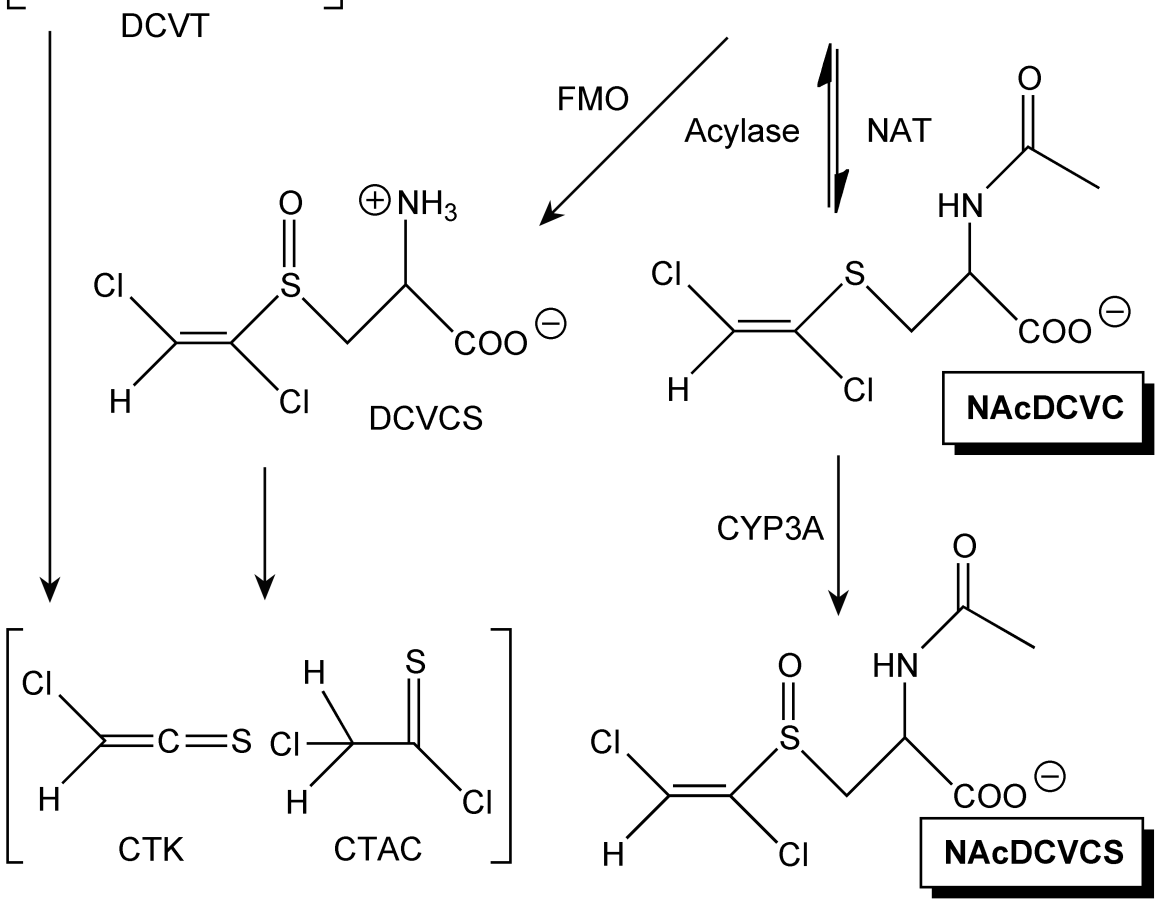

Fig. 2. Scheme for biotransformation of TCE by the GSH conjugation pathway TCE undergoes conjugation with GSH to yield the GSH S-conjugate DCVG. After processing to yield the cysteine S-conjugate DCVC, three potential fates are detoxication to yield the mercapturate NAcDCVC or bioactivation by either the cysteine conjugate $\beta$-lyase to yield dichlorovinylthiol, which rearranges to yield thioacylating species, or the flavincontaining monooxygenase to yield DCVC sulfoxide. The mercapturate can also be deacetylated to regenerate DCVC or it can undergo CYP3A-dependent sulfoxidation. Names of metabolites that are recovered in urine are shown in boxes and those that are chemically 
unstable or reactive are shown in brackets. Abbreviations: CYP3A, cytochrome P-450 3A; CTAC, chlorothionoacetyl chloride; CTK, chlorothioketene; DCVC, S-(1,2-dichlorovinyl)L-cysteine; DCVG, S-(1,2-dichlorovinyl)glutathione; DCVCO, DCVC sulfoxide; DCVT, 1,2-dichlorovinylthiol; DP, dipeptidase; FMO, flavin-containing monooxygenase; GGT, $\gamma$ glutamyltransferase; GSH, glutathione; GST, GSH S-transferase; NAcDCVC, N-acetyl-S(1,2-dichlorovinyl)-L-cysteine; NAcDCVCS, NAcDCVC sulfoxide; NAT, Nacetyltransferase. 


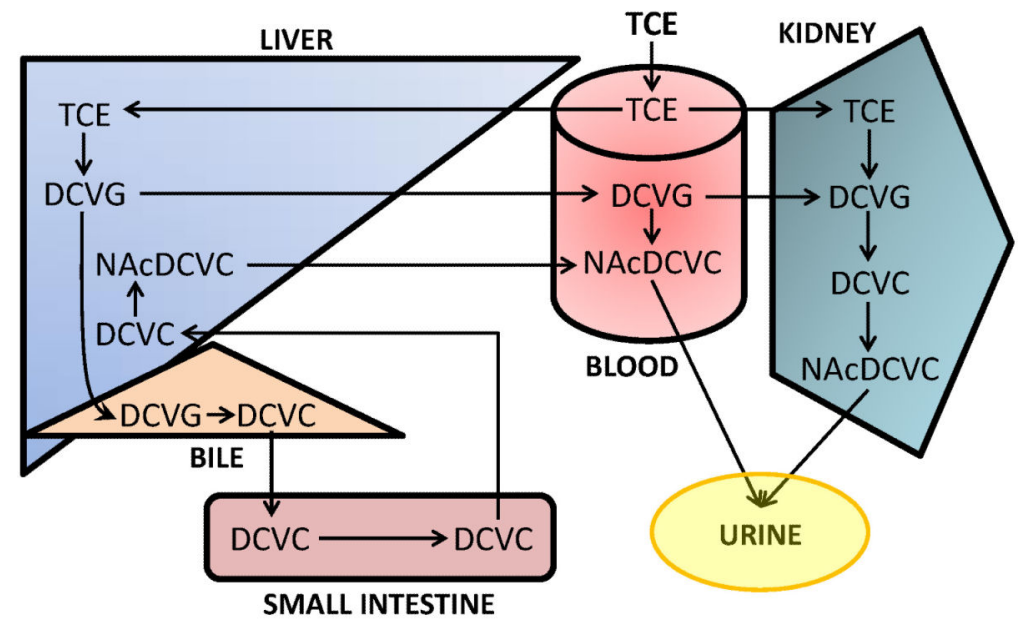

Fig. 3. Inter-organ pathways for metabolism of TCE by the GSH conjugation pathway The scheme summarizes the tissue localization of metabolic reactions and membrane transporters involved in whole body metabolism of TCE by the GSH conjugation pathway. Most of the DCVG formation occurs in the liver, which is very efficient at excreting it into bile or plasma. Biliary DCVG is processed to yield the cysteine conjugate DCVC, which then returns to the liver by enterohepatic recirculation. Most of the hepatic DCVC is Nacetylated to form the mercapturate NAcDCVC, which is efficiently excreted into plasma. Plasma DCVG and NAcDCVC move through the blood and are extracted by the kidneys. DCVG formation also occurs, although to a lesser extent, within the kidneys themselves. 
Table 1

Summary of metabolite formation and systemic availability for TCE

\begin{tabular}{|c|c|c|}
\hline $\begin{array}{c}\text { Compound or } \\
\text { metabolite }\end{array}$ & 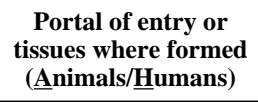 & $\begin{array}{c}\text { Systemic } \\
\text { availability } \\
(\mathbf{A} / \mathbf{H})\end{array}$ \\
\hline TCE & $\begin{array}{l}\text { Lung } \\
\text { GI } \\
\text { Skin }\end{array}$ & Yes $(\mathrm{A}, \mathrm{H})$ \\
\hline \multicolumn{3}{|c|}{ TCE metabolites through CYP-dependent oxidation pathway } \\
\hline $\begin{array}{l}\text { TCE-O } \\
\text { DCAC }\end{array}$ & $\begin{array}{l}\text { Liver (A, H) } \\
\text { Lung (A, H) } \\
\text { Testes (A, H) }\end{array}$ & No \\
\hline CH/CHL & $\begin{array}{l}\text { Liver (A, H) } \\
\text { Lung (A, H) } \\
\text { Testes (A, H) }\end{array}$ & Yes \\
\hline TCOH & $\begin{array}{c}\text { Liver (A, H) } \\
\text { Lung (A) } \\
\text { GI (A, H) } \\
\text { Testes (A, H) }\end{array}$ & Yes \\
\hline TCA & $\begin{array}{l}\text { Liver (A, H) } \\
\text { Lung (A, H) } \\
\text { Testes (H) }\end{array}$ & Yes \\
\hline TCOG & Liver $(\mathrm{A}, \mathrm{H})$ & Yes \\
\hline DCA & $\begin{array}{l}\text { Liver (A) } \\
\text { Lung (A) } \\
\text { Testes (H) }\end{array}$ & $\begin{array}{c}\text { Yes } \\
\text { (low amount) }\end{array}$ \\
\hline \multicolumn{3}{|c|}{ TCE metabolites through GSH conjugation pathway } \\
\hline DCVG & $\begin{array}{c}\text { Liver (A, H) } \\
\text { Kidney }(A, H)\end{array}$ & Yes \\
\hline DCVC & $\begin{array}{c}\text { Liver (A, H) } \\
\text { Kidney }(\mathrm{A}, \mathrm{H})\end{array}$ & Yes \\
\hline $\begin{array}{c}\text { DCVCT } \\
\text { DCVCS } \\
\text { CTK/CTAC }\end{array}$ & $\begin{array}{c}\text { Kidney (A, H) } \\
\text { Hematopoietic (A) }\end{array}$ & No \\
\hline $\begin{array}{c}\text { NAcDCVC } \\
\text { NAcDCVCS }\end{array}$ & $\begin{array}{c}\text { Liver (A, H) } \\
\text { Kidney }(A, H)\end{array}$ & Yes \\
\hline
\end{tabular}

